\title{
連成を考慮した吊橋の基礎方程式および風荷重を 受けた場合への応用*
}

\author{
FUNDAMENTAL EQUATIONS OF A STIFFENED SUSPENSION BRIDGE \\ CONSIDERING COUPLED DEFORMATIONS AND ITS APPLICATION TO \\ THE SYSTEM SUBJECTED TO WIND LOADS
}

高 橋 和 雄**.室 井智 文***.平 野 厳****

By Kazuo TAKAHASHI, Tomofumi MUROI and Iwao HIRANO

\section{1. 緒言}

構造物に風が作用すれば，構造物の空力特性により定 まった抗力, 揚力および空力モーメントの 3 分力が発生 する. 特に吊橋は振動しやすい構造であるために, 空気 力を動的なものとして取扱い，その空気力に対する吊橋 の動的挙動を正しく把握することが必要である. しか し，現実には吊橋の風に対する動的応答が複雑であるた めに他の一般の橋梁と同様の手法を用いて解析検討され ている.すなわち，まず空気力を静的な荷重に置き換え て応力解析を行い，これらの結果に基づいて各部構造を 設計する.ついで，その設計案に対する風洞模型実験な どを行って動力学的見地から安全性を検討するという手 段が採用されていることは周知のとおりである

本題の理論的取扱いは, 一般に補剛桁とケーブルの水 平変位が卓越するために抗力のみが検証されている.す なわち, 抗力による吊橋の水平変位について Moisseiff ${ }^{5)}$ が理論解析上の基礎を築き,その後 Topaloff ${ }^{6)}$, Erzen $^{7)}$, 伊藤 ${ }^{8)}$ らによってフーリエ級数および差分方程式などを 応用した解析法が確立された.また，最近では，Boynton らの提案したマトリックス構造解析法"9) や補剛桁のねじ りおよびずれを考慮した小松・西村の理論的研究 ${ }^{10)}$ があ る.

しかしながら，補剛桁とケーブルの水平横変位差やケ 一ブルの空間幾何曲線，補剛析の橋軸方向の道路縦断線 形（Profile）による初期曲率などの構造特性のために， 補剛桁には鉛直変位, 水平横変位およびねじりの各変位 が連成的に生じ，水平横変位のみ独立に取扱うことは不

* 本研究は土木学会第 30 回年次学術講演会において一部 発表ずみである1).

** 正会員 工修 長崎大学助教授 工学部土木工学科

*** 正会員 日本道路公団

**** 正会員 日本鋼管工事（株）長大橋プロジェクト技術チ -ム
可能である. 特に，長支間吊橋において補剛析およびケ 一ブルの水平横変位が相当に大きくなる場合や，吊橋の 補剛桁の断面形状に関して揚力および空力モーメント成 分が無視できない場合には，3 分力をもつ風荷重を受け る各変形の連成効果を考慮する必要があることはいうま でもない，これまでのところ，横荷重および偏心鉛直荷 重が載荷される場合について, 各変形の連成を考慮した 基礎方程式が島田 ${ }^{11)}$ ・倉西 ${ }^{12)}$ によって誘導されているの みで, 3 分力をもつ風荷重を受ける各変形の連成効果を 考慮した取扱いはなされていないようである ${ }^{13)}$.そこで 本研究では，これら 3 変形の連成を考慮した吊橋の解析 理論の確立を意図するものである.すなわち,まず補剛桁 の道路縦断曲線による初期曲率を有する吊橋に関して, 3 変形の連成を考慮した基礎方程式を, 静的微小変形の 範囲で, 最小ポテンシャルエネルギーの原理を用いて誘 導する. 周知のように, 本法の特徴は材料力学ですでに 認められている基本的仮定のみ（すなわち，断面不変， せん断変形は St. Venant のせん断変形のみを考慮す る $^{14)}$ ) を用いて, 後は数学的演算のみで基礎方程式を誘 導することができるために, 複雑な構造系への適用が容 易である利点をもつ.

また，吊橋のケーブルは水平横方向にサグを持たない ので載荷によるケーブルの活荷重水平張力の変化はケー ブルの鉛直変位のみによって生ずるものとされている.

しかしながら，長支間吊橋では抗力による水平横変位が かなり大きいために，ケーブルの水平横変位が吊橋の力 学的挙動に及ぼす影響も無視 できないものと 推測され る. そこで本論ではケーブルの水平横変位をも考慮した ケーブル方程式を導いている．確立した基礎方程式の解 析にあたっては，ガラーキン法を適用し，また，変位の 適合条件式として得られるハンガーの傾斜角を末知数に 加えるという手法を用いたが，本法は級数の展開に無理 がないために, 従来の手法に比し無限級数の収束を良好 なものにならしめることが可能となった. 


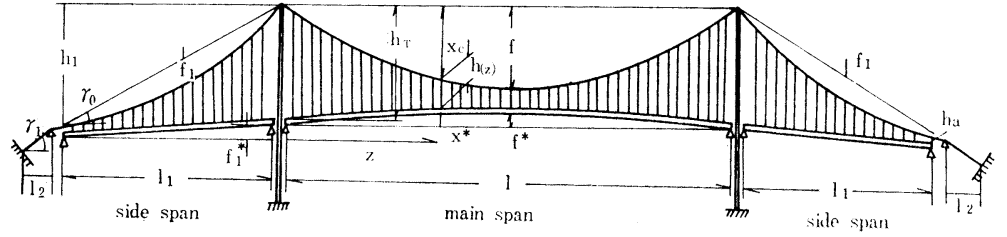

Fig. 1 Geometry of a suspension bridge

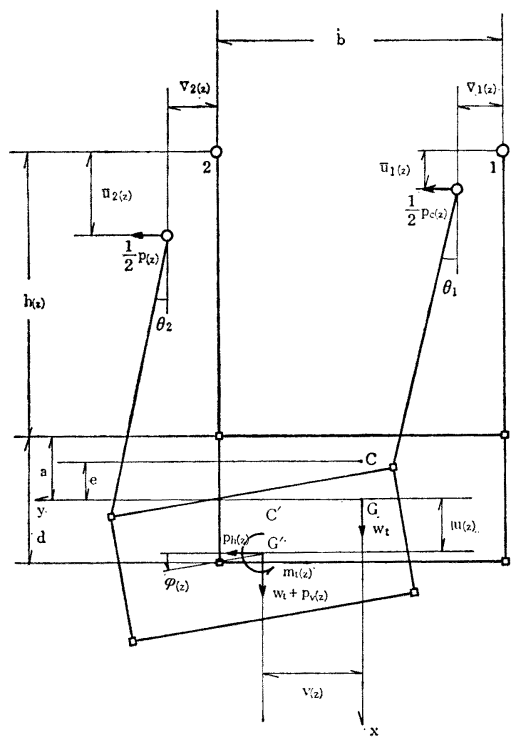

Fig. 2 Co-ordinate system and loads applied to the cross-section

数値計算では 3 分力をもつ風荷重を受ける吊橋の変形 と応力について検討を行い, 解の収束性, ケーブルの活 荷重水平張力の影響, 初期曲率の影響㧍よび風の迎元角 の影響などについて詳細に検討し，その結果を報告する ものである.

\section{2. 一般図および記号}

解析の対象とした 3 径間単純吊橋の一般図および断面 図は Fig. 1 および 2 に示すとおりである.また，本 論では次の記号を用いた。

$l:$ 補剛析中央径間長 $(\mathrm{m})$

$f:$ ケーブルサグ $(\mathrm{m})$

$h_{T}$ : タワーハンガー点でのハンガーの長さ $(\mathrm{m})$

$h_{1}:$ 側径間の陸側橋台のケーブルより塔頂までの 高さ (m)

$h_{a}:$ 側径間の陸側橋台位置におけるケーブルより 上弦材までの距離 $(\mathrm{m})$

$a:$ 補剛析の重心と上弦材中心（またはハンガー 取付点）の距離 (m)

$e:$ 補剛桁のせん断中心と重心との距離 $(\mathrm{m})$
率 $(1 / \mathrm{m})$

$$
\begin{aligned}
x_{c}(z): & \text { 吊橋完成時のケーブル形 } \\
& \text { 状 }(\mathrm{m}) \\
x_{i}{ }^{*}(z) & : \text { 吊橋完成時の補剛桁の縌 } \\
& \text { 断線形 }(\mathrm{m}) \\
h(z) & : \text { ハンガー長 }(\mathrm{m}) \\
\psi & : \text { ケーブルの傾斜角 (rad.) }
\end{aligned}
$$

$\kappa:$ 補剛桁の道路 綎断曲線 (Profile) による初期曲
$L_{E}:$ ケーブルの形状長さ（全径間の合計長) (m) $L_{T}$ : ケーブルの温度応力長さ（全径間の合計長）

(m)

$r_{0}, \gamma_{1}:$ ケーブルの水平角 (rad.)

$I_{v}:$ 補剛桁の鉛直方向断面 2 次モーメント ( $\mathrm{m}^{4} /$ Bridge $)$

$I_{h}:$ 補剛枌の水平方向断面 2 次モーメント ( $\mathrm{m}^{4} /$ Bridge)

$J$ : 補剛桁の St. Venant のねじり剛性 $\left(\mathrm{m}^{4} /\right.$ Bridge $)$

$\mathrm{I}_{\omega}:$ 補剛桁の曲げねじり剛性 ( $\mathrm{m}^{6} /$ Bridge $)$ $A_{c}:$ 主ケーブルの断面積 ( $\mathrm{m}^{2} /$ Cable $)$

$H_{w}$ : 吊橋の死荷重によるケーブルの水平張力 (t/Cable)

$H_{p i}$ : 吊橋の活荷重によるケーブル $i$ の水平張力 (t/Cable)

$w_{t}$ : 補剛桁の単位長さあたりの死荷重 $(\mathrm{t} / \mathrm{m})$ $w_{c}:$ ケーブルの単位長さあたりの死荷重 $(\mathrm{t} / \mathrm{m})$ $p_{v}(z)$ : 補剛桁に作用寸る鉛直方向活荷重 $(\mathrm{t} / \mathrm{m})$ $p_{h}(z)$ : 補剛桁に作用する水平横方向（橋軸直角方 向）活荷重 $(\mathrm{t} / \mathrm{m})$

$m_{t}(z)$ : 補析剛の図心に作用するねじりモーメント荷 重 $(\mathrm{t} \cdot \mathrm{m} / \mathrm{m})$

$u(z):$ 補剛桁の図心の鉛直変位 $(\mathrm{m})$

$\bar{u}_{i}(z):$ ケーブル $i$ の鉛直変位 $(\mathrm{m})$

$v(z)$ : 補剛桁の図心の水平横変位 $(\mathrm{m})$

$\bar{v}_{i}(z):$ ケーブル $i$ の水平横変位 $(\mathrm{m})$

$\varphi(z)$ : 補剛桁の図心まわりのねじり角 ( $\mathrm{rad}$.)

$\bar{w}_{i}(z):$ ケーブル $i$ の橋軸方向変位 $(\mathrm{m})$

$\theta_{i}(z):$ ハンガー $i$ の傾斜角 (rad.)

$E:$ 鋼の弾性係数 $\left(\mathrm{t} / \mathrm{m}^{2}\right)$

$E_{c}:$ ケーブルの弾性係数 $\left(\mathrm{t} / \mathrm{m}^{2}\right)$

$G:$ 鋼のせん断弾性係数 $\left(\mathrm{t} / \mathrm{m}^{2}\right)$

$\Delta T:$ 温度変化 $\left({ }^{\circ} \mathrm{C}\right)$

$\alpha_{T}:$ 鋼の線膨張係数 $\left(1 /{ }^{\circ} \mathrm{C}\right)$

$D_{t}(z)$ : 補剛桁に作用する風荷重の抗力成分 $(\mathrm{t} / \mathrm{m} /$ Bridge $)$

$D_{c}(z)$ : ケーブルに作用する風荷重の抗力成分 
$(\mathrm{t} / \mathrm{m} /$ Bridge $)$

$L_{t}(z)$ : 補剛桁に作用する風荷重の揚力成分 $(\mathrm{t} / \mathrm{m} /$ Bridge $)$

$M_{t}(z)$ : 補剛桁に作用する風荷重の空力モーメント成 分 $(\mathrm{t} \cdot \mathrm{m} / \mathrm{m} /$ Bridge $)$

$V(z):$ 風速 $(\mathrm{m} / \mathrm{sec})$

$\alpha(z)$ : 風の迎之角 (rad.)

$\rho:$ 風の密度 $\left(t \cdot \sec ^{2} / \mathrm{m}^{4}\right)$

$C_{D}:$ 補剛林の抗力係数

$C_{L}:$ 補剛桁の揚力係数

$C_{M}:$ 補剛桁の空力モーメント係数

$A_{D}$ : 補剛桁の有効鉛直投射面積 $\left(\mathrm{m}^{2} / \mathrm{m}\right)$

$A_{L}$. 補剛桁の水平投射面積 $\left(\mathrm{m}^{2} / \mathrm{m}\right)$

$M_{v}$ : 補剛桁の鉛直方向曲げモーメント $(\mathrm{t} \cdot \mathrm{m})$

$M_{h}: \quad$ ＼cjkstart水平横方向曲げモーメント $(\mathrm{t} \cdot \mathrm{m})$

$T:$ " 合ねじりモーメント $(\mathrm{t} \cdot \mathrm{m})$

$M_{\omega}: \quad$ "曲げねじりモーメント $\left(\mathrm{t} \cdot \mathrm{m}^{2}\right)$

$P_{h}:$ "水平横方向せん断力 (t)

$P_{v}: \quad$ ～鉛直方向せん断力 $(\mathrm{t})$

$U, V, W$ : 補剛析の任意点 $(x, y, z)$ の変位 $(\mathrm{m})$ $\varepsilon_{x}, \varepsilon_{y}, \varepsilon_{z}, r_{x y}, r_{z x}, r_{z y}:$ 補剛桁のひずみ成分 $(\mathrm{m} / \mathrm{m})$ $\sigma_{x}, \sigma_{y}, \sigma_{z}, \tau_{x y}, \tau_{z x}, \tau_{z y}:$ 補剛桁の応力成分 $\left(\mathrm{t} / \mathrm{m}^{2}\right)$ $\omega(x, y):$ 規準化された St. Venant のゆがみ関数 $\left(\mathrm{m}^{2}\right)$

以上は中央径間についての記号であり，側径間について は上記記号に，サフィクス“1”をつけることにする.

\section{3. 解析上の基本的仮定}

本題の解析にあたっては 次のような諸事項を仮定す る.

（a）ケーブルは完全な可暁性を有する.

（b）ケーブルおよび補剛林の単位長さあたりの死荷 重および断面性能は各径間ごとに一定である.

(c) 補剛桁の断面は左右対称である.

（d）塔の伸縮および曲げを無視する.

（e）ケーブルおよび補剛桁の死荷重はケーブルのみ によって支えられる，したがって，活荷重が作用しない 場合の補剛桁は完全に無応力である.

（f） ハンガーは非常に密に配置されており，ケーブ ルと補剛桁は連続的にハンガーに連結されている.

（g） ハンガーは垂直で, 載荷によるひずみを無視す る.

（h）補剛析は薄肉断面ばりとみなされ，一般のはり 理論が成立する.

（i）補剛桁の変形は微小で ひずみ一変位関係が 線形 である。また, 応力ーひずみ関係は, フックの法則が成
立する. ケーブルの面外変位についてはひずみ一変位関 係の 2 次の項を考慮する.

（j）補剛桁の軸方向変位を無視する.

（k）ケーブルの傾斜角は載荷後も一定で, かつケー ブルの定着点では不動である.

（1）載荷に伴うハンガーの橋軸方向の傾斜を無視す る.

（m）補剛桁の鉛直断面の図心に鉛直荷重, 水平横荷 重およびねじりモーメントからなる荷重が作用する.ケ ーブルには水平横荷重のみが作用する.

(n) ケーブルの水平張力は塔上で連続する.

（o）吊橋の完成時の橋軸方向の道路縦断曲線（Profile) は中央径間では放物線, 側径間では直線とする. ただし, 吊橋の中央径間の道路縦断曲線による初期曲率 は小さいので, 補剛桁の解析にあたっては等価な円弧に 近似する.

\section{4.ひずみの定義}

\section{（1）補 剛 椼}

Fig. 1 に示すように補剛桁の左側支承にスパン方向 に絶対座標の $z$ 軸をとり, Fig. 2 の断面の図心を原点 に $x, y$ 軸を定める. なお, 道路縦断曲線による初期曲 率は十分に小さいので断面の図心軸は近似的に絶対座標 の $z$ 軸に合致するものとする. 仮定 (h) および (j)に より断面剛の仮定を用いてはり内の任意点の $x, y, z$ 方 向の変位 $U, V, W$ を求めれば次のとおりである ${ }^{14)}$.

$$
\begin{aligned}
U(x, y, z)= & u(z)-y \varphi(z) \\
V(x, y, z)= & v(z)+x \varphi(z) \\
W(x, y, z)= & -x u^{\prime}(z)-y v^{\prime}(z) \\
& +\left(\varphi^{\prime}+\kappa v^{\prime}\right) \omega(x, y)
\end{aligned}
$$

テンソル解析により, 式 (1) の変位による補剛桁のひ ずみは次のように与えられる ${ }^{15)}$.

$$
\begin{aligned}
& \varepsilon_{x}=\varepsilon_{y}=r_{x y}=0 \\
& \varepsilon_{z}=-\kappa u-x u^{\prime \prime}-y \Omega_{v}+\varphi \Omega_{\varphi} \\
& r_{z x}=-\left(y-\frac{\partial \omega}{\partial x}\right) \Gamma_{\varphi} \\
& r_{z y}=\left(x+\frac{\partial \omega}{\partial y}\right) \Gamma_{\varphi}
\end{aligned}
$$

ここに, $\Omega_{v}=v^{\prime \prime}-\kappa \varphi, \Omega_{\varphi}=\Gamma_{\varphi}{ }^{\prime}, \Gamma_{\varphi}=\varphi^{\prime}+\kappa v^{\prime}, '$ は $z に$ 関する微分を示す.

\section{(2) ケーブル}

Fig. 3 に示すようにケーブルの 微小要素 $d s$ が変形 後 $d \vec{s}$ に変化したものとする. 初期たわみ状態 $\left(x_{c}, y_{c}\right.$, z) からのケーブルの変位 $(\bar{u}, \bar{v}, \bar{w})$ を $z$ のの関数 と考えると初期状態における線素 $d s$ および変形後にお 


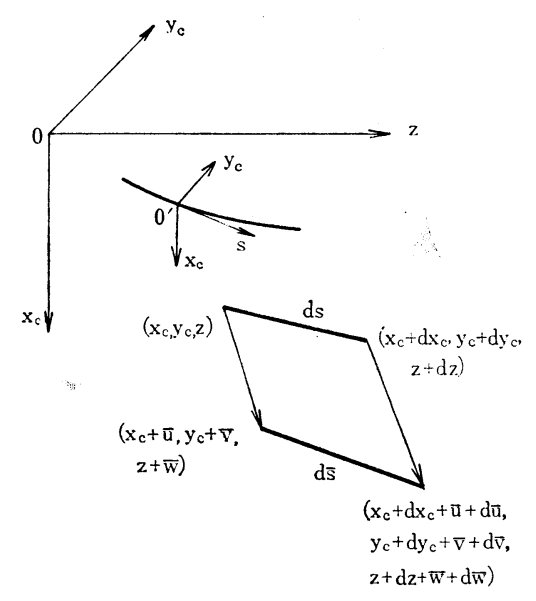

Fig. 3 An infinitely small element of the cable

ける線素 $d \bar{s}$ は次のように表わされる.

$$
\left.\begin{array}{rl}
d s= & \left(d x_{c}{ }^{2}+d y_{c}{ }^{2}+d z^{2}\right)^{1 / 2}=\left(1+x_{c}{ }^{\prime 2}+y_{c}{ }^{\prime 2}\right)^{1 / 2} d z \\
d \bar{s}= & \left\{\left(d x_{c}+d \bar{u}\right)^{2}+\left(d y_{c}+d \bar{v}\right)^{2}+(d z+d \bar{w})^{2}\right\}^{1 / 2} \\
= & \left(x_{c}{ }^{\prime 2}+2 x_{c}{ }^{\prime} \bar{u}^{\prime}+y_{c}{ }^{\prime 2}+2 y_{c}{ }^{\prime} \bar{v}^{\prime}+\bar{u}^{\prime 2}+\bar{v}^{\prime 2}+1\right. \\
& \left.+2 \bar{w}^{\prime}+\bar{w}^{\prime 2}\right)^{1 / 2} d z
\end{array}\right\}
$$

Fig. 1 に示す吊橋においてケーブルの変形の原点を吊 橋の完成時の安定状態とし，仮定 (b) および（e）によ りケーブルの初期たわみを求めれば次のとおりである.

$$
x_{c}=-4 f(z-l) z / l^{2}, y_{c}=0
$$

式（3）および式（4）を用いてケーブルのひずみが次の ように得られる。

$$
\begin{aligned}
& \varepsilon_{c}=(d \bar{s}-d s) / d s=\bar{w}^{\prime}+\frac{1}{2} \bar{w}^{\prime 2}+x_{c} \bar{u}^{\prime}+\frac{1}{2} \bar{u}^{\prime 2} \\
& +\frac{1}{2} \bar{v}^{\prime 2}
\end{aligned}
$$

\section{5. 吊橋全体のポテンシャルエネルギー}

\section{（1）補剛桁のひずみエネルギー}

補剛桁のひずみエネルギーはフックの法則を用いて次 のように表わされる.

$$
\begin{aligned}
V_{t}= & \frac{1}{2} \iiint\left(\sigma_{z_{z}}+\tau_{z x} \gamma_{z x}+\tau_{z y} \gamma_{z y}\right) d x d y d z \\
= & \frac{1}{2} E \iiint\left(-\kappa u-x u^{\prime \prime}-y \Omega_{v}+\varphi \Omega_{\varphi}\right)^{2} d x d y d z \\
& +\frac{1}{2} G \iiint\left\{\left(y-\frac{\partial \omega}{\partial x}\right)^{2}\right. \\
& \left.+\left(x+\frac{\partial \omega}{\partial y}\right)^{2}\right\} \Gamma_{\varphi}^{2} d x d y d z \cdots \cdots \cdots \cdots \cdots(6)
\end{aligned}
$$

\section{（2）ケーブルのひずみエネルギー}

ケーブル $i$ のひずみエネルギーは死荷重による初期
応力 $\sigma_{c i}=$ 一定による項と活荷重による付加応力 $\sigma_{c i}$ に よる項との和で与えられ，次のとおりである.

$$
\begin{aligned}
V_{c i}= & \iiint \bar{\sigma}_{c i} \varepsilon_{c i} d x_{c} d y_{c} d s \\
& +\frac{1}{2} \iiint \sigma_{c i} \varepsilon_{c i} d x_{c} d y_{c} d s
\end{aligned}
$$

$$
\text { ここに, } i=1,2
$$

上式を慣用のケーブル張力の水平成分を用いて表わせ ば,

$$
\begin{aligned}
& V_{c i}=H_{w} \int_{0}^{l}\left(\bar{w}_{i}{ }^{\prime}+\frac{1}{2} \bar{w}_{i}{ }^{\prime 2}+x_{c}{ }^{\prime} u_{i}{ }^{\prime}+\frac{1}{2} \bar{u}_{i}{ }^{2}\right. \\
& \left.+\frac{1}{2}{\bar{v}_{i}}^{\prime 2}\right) d z+\frac{1}{2} H_{p i} \int_{0}^{l}\left(\bar{w}_{i}{ }^{\prime}+\frac{1}{2} \bar{w}_{i}{ }^{\prime 2}\right. \\
& \left.+x_{c}{ }^{\prime} \bar{u}_{i}{ }^{\prime}+\frac{1}{2} \bar{u}_{i}{ }^{2}+\frac{1}{2}{\bar{v}_{i}}^{\prime 2}\right) d z \\
& \text { ここに, } H_{w}=\iint \bar{\sigma}_{c i} d x_{c} d y_{c} \frac{d z}{d s} \\
& H_{p i}=\iint \sigma_{c i} d x_{c} d y_{c} \frac{d z}{d s}
\end{aligned}
$$

本論では仮定（g）によりハンガーは伸びないとしたの で, ケーブルの 鉛直変位 $\bar{u}_{i}$ は補剛桁の 鉛直変位 $u$ お よびねじり $\varphi$ を用いて次のように表わすことができる.

$$
\bar{u}_{1}=u-\frac{1}{2} b \varphi, \bar{u}_{2}=u+\frac{1}{2} b \varphi
$$

なお，仮定（j）および（1）により補剛桁の橋軸方向の 変位およびハンガーの橋軸方向の傾斜を無視するため, 以下の誘導にあたっては式（8）に含まれるケーブルの 橋軸方向の変位 $\bar{w}_{i}$ を無視し, ケーブル方程式の項で考 慮することにする.

\section{（3）ハンガーの水平横方向傾斜によるエネルギー}

仮定（g）によってハンガーはひずまないと仮定した が, Fig. 2 に示すよらにハンガーの伝播する力の水平 横成分がケーブルと補剛桁との間に生ずる相対変位だけ 仕事をすることになる. 図においてハンガーの力の水平 横成分は既知の補剛析に作用寸る荷重を用いて,

$$
r_{i}=\frac{1}{2}\left(p_{v}+w_{t}\right)\left(1 \pm \frac{2 a}{b} \varphi\right) \theta_{i}
$$

上式におけるハンガー $i$ の傾斜角 $\theta_{i}$ は仮定 $(\mathrm{g}),(\mathrm{j})$ および (1) からケーブルおよび補剛析の各変位間の適 合条件を満足しなければならないことから次のように求 められる.

$$
h \theta_{i}=v-\bar{v}_{i}+a \varphi
$$

式（10）および（11）を用いて，ハンガーのなす仕事を 求めれば, 次のとおりである.

$$
\begin{aligned}
V_{h} & =\frac{1}{2} \sum_{i} \int\left\{r_{i}\left(v-\bar{v}_{i}+a \varphi\right)\right\} d z \\
& =\frac{1}{4} \int\left(p_{v}+w_{t}\right) h\left({\theta_{1}}^{2}+\theta_{2}{ }^{2}\right) d z
\end{aligned}
$$




\section{（4）荷重のなす仕事}

仮定 (m) により，Fig. 2 に示すような 荷重が補剛 桁およびケーブルに作用するものとする. それらの力が 保存系のとき荷重のなす仕事は,

$$
\begin{aligned}
W_{e}= & \int\left\{\left(p_{v}+w_{t}\right) u+p_{h} v+m_{t} \varphi+\frac{1}{2} w_{c}\left(\bar{u}_{1}+\bar{u}_{2}\right)\right. \\
& \left.+\frac{1}{2} p_{c}\left(\bar{v}_{1}+\bar{v}_{2}\right)\right\} d z \cdots \cdots \cdots \cdots \cdots \cdots \cdots(13)
\end{aligned}
$$

したがうて，吊橋全体のポテンシャルエネルギーＩは 式 (6)，(8)，(12）および（13）を用いて, 次のように 求められる.

$$
\Pi=V_{t}+V_{c 1}+V_{c 2}+V_{h}-W_{e}
$$

\section{6. 基礎方程式および境界条件}

吊橋の基礎方程式を得るために最小ポテンシャルエネ ルギーの原理を適用する. すなわち，

$$
\delta \Pi=\delta V_{t}+\delta V_{c 1}+\delta V_{c 2}+\delta V_{h}-\delta W_{e}=0
$$

上式に含まれる $\delta V_{t}$ にフックの 法則を適用して, 体積 積分項にまず面積積分を施し, 仮定 (c) および座標原 点が図心であることを考慮のうえ, 式 (15) を書き改め れば次式が得られる。

$$
\begin{aligned}
\delta \Pi= & \int\left[E \left\{I_{v} u^{\prime \prime} \delta u^{\prime \prime}+I_{h} \Omega_{v} \delta \Omega_{v}+I_{\omega} \Omega_{\varphi} \delta \Omega_{\varphi}\right.\right. \\
& \left.-I_{y_{\omega}}\left(\Omega_{v} \delta \Omega_{\varphi}+\Omega_{\varphi} \delta \Omega_{v}\right)\right\}+G J \Gamma_{\varphi} \delta \Gamma_{\varphi} \\
& +\sum_{i}\left\{\left(H_{w}+H_{p i}\right)\left(x_{c}{ }^{\prime}+\bar{u}_{i}{ }^{\prime}\right) \delta \bar{u}_{i}{ }^{\prime}\right. \\
& \left.+\left(H_{w}+H_{p i}\right) \bar{v}_{i}{ }^{\prime} \delta \bar{v}_{i}{ }^{\prime}\right\} \\
& +\frac{1}{2}\left(p_{v}+w_{t}\right)\left(\theta_{1} \delta \theta_{1}+\theta_{2} \delta \theta_{2}\right) \\
& -\left\{\left(p_{v}+w_{t}\right) \delta u+p_{h} \delta v+m_{t} \delta \varphi\right. \\
& +\frac{1}{2} w_{c}\left(\delta \bar{u}_{1}+\delta \bar{u}_{2}\right) \\
& \left.\left.+\frac{1}{2} p_{c}\left(\delta \bar{v}_{1}+\delta \bar{v}_{2}\right)\right\}\right] d z=0 \cdots \cdots . . .
\end{aligned}
$$

ここに,

$$
\begin{aligned}
& I_{v}=\int_{A} x^{2} d A, I_{h}=\int_{A} y^{2} d A \\
& I_{y_{\omega}}=\int_{A} y \omega d A, I_{\omega}=\int_{A} \omega^{2} d A, \\
& J=\int_{A}\left\{\left(y-\frac{\partial \omega}{\partial x}\right)^{2}+\left(x+\frac{\partial \omega}{\partial y}\right)^{2}\right\} d A
\end{aligned}
$$

補剛桁に㗢いている応力の合力から得られる断面力を次 のように定義する ${ }^{14)}$.

$$
\left.\begin{array}{l}
M_{h}=\int_{A} \sigma_{z} y d A, M_{v}=-\int_{A} \sigma_{z} x d A, \\
M_{\omega}=\int_{A} \sigma_{z} \omega d A, M_{s}=\int_{A}\left(\tau_{z y} x-\tau_{z x} y\right) d A, \\
T=M_{s}-M_{\omega}^{\prime}, P_{v}=M_{v}^{\prime}, P_{h}=M_{h}^{\prime}+\kappa T
\end{array}\right\}
$$

上式を式(2)を用いて変位で表わせば, 次式が得られる.

$$
\begin{aligned}
M_{h}= & E\left\{-I_{h}\left(v^{\prime \prime}-\kappa \varphi\right)+I_{y_{\omega}}\left(\varphi^{\prime \prime}+\kappa v^{\prime \prime}\right)\right\}, \\
M_{v}= & -E I_{v} u^{\prime \prime}, \\
M_{\omega}= & E\left\{-I_{y \omega}\left(v^{\prime \prime}-\kappa \varphi\right)+I_{\omega}\left(\varphi^{\prime \prime}+\kappa v^{\prime \prime}\right)\right\}, \\
M_{s}= & G J\left(\varphi^{\prime}+\kappa v^{\prime}\right), \\
T= & E\left\{I_{y_{\omega}}\left(v^{\prime \prime \prime}-\kappa \varphi^{\prime}\right)-I_{\omega}\left(\varphi^{\prime \prime \prime}+\kappa v^{\prime \prime \prime}\right)\right\} \\
& +G J\left(\varphi^{\prime}+\kappa v^{\prime}\right), \\
P_{v}= & -E I_{v} u^{\prime \prime \prime}, \\
P_{h}= & E\left\{-\left(I_{h}-I_{y_{\omega}} \kappa\right)\left(v^{\prime \prime \prime}-\kappa \varphi^{\prime}\right)\right. \\
& \left.+\left(I_{y_{\omega}}-\kappa I_{\omega}\right)\left(\varphi^{\prime \prime \prime}+\kappa v^{\prime \prime \prime}\right)\right\}+G J \kappa\left(\varphi^{\prime}+\kappa v^{\prime}\right)
\end{aligned}
$$

式（16）のひずみを変位で表わし, 部分積分を行い, 式 （17）で定義された断面力を用いると, 積分項に含まれ る任意の仮想変位 $\delta u, \delta \varphi, \delta v, \delta \bar{v}_{1}, \delta \bar{v}_{2}$ に対して式 (16) が成立するための必要十分条件として, 吊橋の平衡方程 式と境界条件が得られることになる。

\section{（1）平衡方程式}

$$
\left.\begin{array}{rl}
-P_{v}^{\prime} & +\left(2 H_{w}+H_{p_{1}}+H_{p_{2}}\right)\left(x_{c}^{\prime \prime}+u^{\prime \prime}\right) \\
& +\left(H_{p_{1}}-H_{p_{2}}\right) \frac{b}{2} \varphi^{\prime \prime}=p_{v}+w_{t}+w_{c} \\
-T^{\prime}+\kappa M_{h}-\left(2 H_{w}+H_{p_{1}}+H_{p_{2}}\right) \frac{b^{2}}{4} \varphi^{\prime \prime} & \\
& +\frac{b}{2}\left(H_{p_{1}}-H_{p_{2}}\right)\left(x_{c}^{\prime \prime}+u^{\prime \prime}\right) \\
& +\frac{a}{2}\left(w_{t}+p_{v}\right)\left(\theta_{1}+\theta_{2}\right)=m_{t}, \\
-P_{h}{ }^{\prime} & +\frac{1}{2}\left(p_{v}+w_{t}\right)\left(\theta_{1}+\theta_{2}\right)=p_{h}, \\
\left(H_{w}+H_{p_{1}}\right) \bar{v}_{1}^{\prime \prime}+\frac{1}{2}\left(p_{v}+w_{t}\right) \theta_{1}=-\frac{1}{2} p_{c}, \\
\left(H_{w}+H_{p_{2}}\right) \bar{v}_{2}^{\prime \prime}+\frac{1}{2}\left(p_{v}+w_{t}\right) \theta_{2}=-\frac{1}{2} p_{c}
\end{array}\right\}
$$

上式を仮定（e）および（o）および式（18）を用いて変 形の微分方程式に書き改めれば, $E I_{v} u^{(4)}-\left(2 H_{w}+H_{p_{1}}+H_{p_{2}}\right) u^{\prime \prime}$

$$
\begin{aligned}
&+\left(H_{p_{1}}-H_{p_{2}}\right) \frac{b}{2} \varphi^{\prime \prime}=p_{v}+\left(H_{p_{1}}+H_{p_{2}}\right) x_{c}{ }^{\prime \prime} \\
&\left(H_{p_{1}}-H_{p_{2}}\right) \frac{b}{2} u^{\prime \prime}+E I_{\omega} \varphi^{(4)}-\left(G J-2 \kappa E I_{y \omega}\right) \varphi^{\prime \prime}-\left(2 H_{w}+H_{p_{1}}+H_{p_{2}}\right) \frac{1}{4} b^{2} \varphi^{\prime \prime}+E I_{h^{2}} \kappa^{2} \\
&-E\left(I_{y \omega}-\kappa I_{\omega}\right) v^{(4)}+\kappa\left(E \kappa I_{y \omega}-E I_{h}-G J\right) v^{\prime \prime} \\
&+a\left(p_{v}+w_{t}\right) \frac{1}{2}\left(\theta_{1}+\theta_{2}\right)=m_{t} \\
&-\left(H_{p_{1}}-H_{p_{2}}\right) \frac{b}{2} x_{c}^{\prime \prime}, \\
&-E\left(I_{y \omega}-\kappa I_{\omega}\right) \varphi^{(4)}+\kappa\left(E \kappa I_{y \omega}-E I_{h}-G J\right) \varphi^{\prime \prime} \\
&+E\left(I_{h}-2 I_{y \omega} \kappa+I_{\omega} \kappa^{2}\right) v^{(4)}
\end{aligned}
$$




$$
\begin{array}{r}
-G J \kappa^{2} v^{\prime \prime}+\left(p_{v}+w_{t}\right) \frac{1}{2}\left(\theta_{1}+\theta_{2}\right)=p_{h}, \\
\left(H_{w}+H_{p_{1}}\right) \bar{v}_{1}^{\prime \prime}+\frac{1}{2}\left(p_{v}+w_{t}\right) \theta_{1}=-\frac{1}{2} p_{c}, \\
\left(H_{w}+H_{p_{2}}\right) \bar{v}_{2}^{\prime \prime}+\frac{1}{2}\left(p_{v}+w_{t}\right) \theta_{2}=-\frac{1}{2} p_{c}
\end{array}
$$

ここに, $\kappa=8 f^{*} / l^{2}$

\section{（2） $z=0, l$ における境界条件}

$$
\begin{gathered}
\left\{p_{v}+\left(2 H_{w}+H_{p_{1}}+H_{p_{2}}\right)\left(x_{c}{ }^{\prime}+u^{\prime}\right)\right. \\
\left.-\frac{b}{2}\left(H_{p_{1}}-H_{p_{2}}\right) \varphi^{\prime}\right\} \delta u=0, M_{v} \delta u^{\prime}=0, \\
\left\{T-b\left(H_{p_{1}}-H_{p_{2}}\right)\left(x_{c}{ }^{\prime}+u^{\prime}\right)\right. \\
\left.\quad+\left(2 H_{w}+H_{p_{1}}+H_{p_{2}}\right) \frac{1}{4} b^{2} \varphi^{\prime}\right\} \delta \varphi=0, \\
P_{h} \delta v=0,\left(M_{h}+\kappa M_{\omega}\right) \delta v^{\prime}=0, \\
\left(H_{w}+H_{p_{1}}\right) \bar{v}_{1}^{\prime} \delta \bar{v}_{1}=0, \quad\left(H_{w}+H_{p_{2}}\right) \bar{v}_{2}^{\prime} \delta \bar{v}_{2}=0,
\end{gathered}
$$

基礎方程式には式（20）のほかに, 式（11）の2式が加 わる. 基礎方程式に含まれる末知数 $u, \varphi, v, \bar{v}_{1}, \bar{v}_{2}, \theta_{1}$, $\theta_{2}, H_{p_{1}}, H_{p_{2}}$ の 9 個のちち, $H_{p_{1}}, H_{p_{2}}$ は活荷重によっ て生ずるケーブルの付加水平張力で, 次章に誘導するケ ーブル方程式を用いて求められる.

\section{7. ケーブル方程式}

仮定（j）および（1）に述べたように，長支間吊橋は 支点はローラー支点が多いので, 補剛桁の橋軸方向の 変位およびハンガーの橋軸方向の傾斜を無視することが できるが, ケーブルの活荷重水平張力 $H_{p_{1}}, H_{p_{2}}$ を求め るにあたっては前述のように軸方向変位を考慮する ${ }^{2)}$. ケーブル $i$ の任意点 $\left(x_{c}, z\right)$ の傾斜角 $\psi$ は活荷重載荷 後多少変化するが, 仮定 $(\mathrm{k})$ によって変形後も一定で あるとする. ケーブルの微小部分 $d s$ を近似的に直線と みなせば, 式 (3) の第 1 式から次式を得る.

$$
d s^{2}=d z^{2}+d x_{c}{ }^{2}, d s=d z \sec \psi
$$

活荷重の載荷 および温度変化による変形後には式 (3) の第 2 式を書き改めることにより次のが得られる.

$$
\begin{gathered}
\left(d s+\Delta d s_{i}\right)^{2}=\left(d z+d \bar{w}_{i}\right)^{2} \\
+\left(d x_{c}+d \bar{u}_{i}\right)^{2}+d \bar{v}_{i}{ }^{2}
\end{gathered}
$$

ここで, ケーブルの伸び $\Delta d s_{i}$ は水平張力の増分および 温度変化によるものであるから次のように与えられる。

$$
\Delta d s_{i}=\frac{H_{p i}}{E_{c} A_{c}} d s \sec \psi+\alpha_{T} \Delta T d s
$$

上式の $H_{p i} \sec \psi$ は活荷重によるケーブルの付加張
力である. 長支間吊橋では死荷重によるケーブル張力に 比較して数\%のオーダーであるために，ケーブルのひず み $\Delta d s_{i} / d s$ は微小であることがすでに明らかにされて いる ${ }^{16)}$. 加らるに, 通常の吊橋はサグ比 $f / l=1 / 9 \sim 1 / 12$ の偏平なケーブルを持つことから, 式 (23)の $\Delta d s_{i}{ }^{2} お$ よび $d \bar{w}_{i}{ }^{2}$ は無視することができる.また, 活荷重によ るケーブル水平張力の増加は, 吊橋の静定挙動を押える 方向に作用するから, ケーブルの 鉛直変位 $d \bar{u}_{i}$ はケー ブルの初期形状 $d x_{c}$ に比較して小さいから, $d \bar{u}_{i}{ }^{2}$ も無 視することができる.

ケーブルは水平横方向にサグを持たないために，ケー ブル方程式の誘導にあたってはその水平横変位の影響が 無視されるのが通例である．しかし，長支間吊橋では風 の抗力による水平横変位が支配的になるためただちに無 視するには疑問がある.そこで, 本研究では水平横変位 の 2 次の項まで採用すれば, 式 (22)〜 (24) からケーブ ルの軸方向変位に関する $d \bar{w}_{i}$ が次のように求められ る.

$$
\begin{aligned}
d \bar{w}_{i}= & H_{p i} \frac{\sec ^{3} \psi}{E_{c} A_{c}} d z+\alpha_{T} \Delta T \sec ^{2} \psi d z \\
& -x_{c}{ }^{\prime} \bar{u}_{i}^{\prime} d z-\frac{1}{2} \bar{v}_{i}{ }^{\prime 2} d z \cdots \cdots \cdots \cdots
\end{aligned}
$$

仮定（k）により，ケーブルの定着点が不動であるから，

$$
\int_{c}^{C^{\prime}} d \bar{w}_{i}=\left|\bar{w}_{i}\right|_{C}^{C^{\prime}}=0
$$

Fig. 1 に示すような吊橋を対象として, 仮定 (n) を用 いて式（25）を部分積分すれば次式を得る.

$$
\begin{aligned}
H_{p i}= & \frac{-E_{c} A_{c}}{L_{E}}\left\{\sum _ { j } \left(x_{c}{ }^{\prime \prime} \int_{0}^{l_{j}} \bar{u}_{i} d z\right.\right. \\
& \left.\left.-\frac{1}{2} \int_{0}^{l_{j}} \bar{v}_{i}^{2} d z\right)+\alpha_{T} \Delta T L_{T}\right\}
\end{aligned}
$$

ここに,

$$
\begin{aligned}
L_{E}= & \int_{C}^{c^{\prime}} \sec ^{3} \psi d z \fallingdotseq l\left(1+8 \frac{f^{2}}{l^{2}}\right) \\
& +2 l_{1}\left(1+8 \frac{f_{1}{ }^{2}}{l_{1}{ }^{2}}+\frac{3}{2} \tan ^{2} \gamma_{0}\right)+2 l_{s} \sec ^{3} r_{1} \\
L_{T}= & \int_{c}^{C^{\prime}} \sec ^{2} \psi d z \fallingdotseq l\left(1+\frac{16}{3} \frac{f^{2}}{l^{2}}\right) \\
& +2 l_{1}\left(1+\frac{16 f_{1}{ }^{2}}{3 l_{1}{ }^{2}}+\tan ^{2} r_{0}\right)+2 l_{s} \sec ^{2} r_{1}
\end{aligned}
$$

上式はケーブルの 3 次元的変形を考慮したケーブル方程 式であり, 従来のケーブル方程式とは（ ）の中の第 2 項を考慮している点で異なる.

吊橋が活荷重によって変形するとき，一般に式 (25) に示すようにケーブルの橋軸方向の変位 $\bar{w}_{i}$ が生じ, 補 剛桁との間に相対変位が生ずるためにハンガーは橋軸方 向に傾斜する. 本論では補剛桁扝よびケーブルの鉛直断 面のみに荷重が作用するために仮定（1）によってこの 傾斜を無視している．長支間吊橋のように活荷重による 
ケーブルの伸びが小さく, また, 補剛桁の両支点がローラ 一で橋軸方向に移動可能で, かつ, 荷重が吊橋の中央に 対称で変形が左右対称ならば，このような仮定は十分に 工学的に許されるものである. Melan による慣用の暁度 理論による基礎方程式の誘導にも同じ仮定が採用されて いる.

\section{8. 既往理論との比較}

\section{（1）連成法との比較}

吊橋の鉛直変位, 水平横変位およびねじりの連成を考 慮した断面剛の仮定のもとに誘導された基礎方程式につ いては最近いくつかの研究が見受けられる ${ }^{11), 12), 17), 18) . ~}$ 断面のねじりが小さく, それによって生ずる付加曲げモ ーメントおよび初期曲率による付加ねじりモーメントが 無視できる場合について誘導された基礎方程式は次のよ らに表わされる ${ }^{17)}$.

$$
\begin{aligned}
& E I_{v} u^{(4)}-\left(2 H_{w}+H_{p_{1}}+H_{p_{2}}\right) u^{\prime \prime} \\
&+\left(H_{p_{1}}-H_{p_{2}}\right) \frac{b}{2} \varphi^{\prime \prime}=p_{v}+\left(H_{p_{1}}+H_{p_{2}}\right) x_{c}^{\prime \prime}, \\
& E I_{\omega} \varphi^{(4)}-\left\{G J+b^{2}\left(2 H_{w}+H_{p_{1}}+H_{p_{2}}\right) \frac{1}{4}\right\} \varphi^{\prime \prime} \\
&-E I_{y_{\omega} v^{(4)}}+\left(H_{p_{1}}-H_{p_{2}}\right) \frac{b}{2} u^{\prime \prime} \\
&-\left(H_{w}+H_{p_{1}}\right) a \bar{v}_{1}^{\prime \prime}-\left(H_{w}+H_{p_{2}}\right) a \bar{v}_{2}^{\prime \prime} \\
&=m_{t}+p_{c} a-\left(H_{p_{1}}-H_{p_{2}}\right) \frac{b}{2} x_{c}^{\prime \prime}, \\
& E I_{h} v^{(4)}-E I_{y_{\omega}} \varphi^{(4)}-\left(H_{w}+H_{p_{1}}\right) \bar{v}_{1}^{\prime \prime} \\
&-\left(H_{w}+H_{p_{2}}\right) \bar{v}_{2}^{\prime \prime}=p_{c}+p_{h}, \\
&\left(H_{w}+H_{p_{1}}\right) \bar{v}_{1}^{\prime \prime}-\left\{\left(H_{w}+H_{p_{1}}\right) x_{c}^{\prime \prime}+\frac{1}{2} w_{c}\right\} \theta_{1} \\
&=-\frac{1}{2} p_{c}, \\
&=-\frac{1}{2} p_{c} \\
&\left(H_{w}+H_{p_{2}}\right) \bar{v}_{2}^{\prime \prime}-\left\{\left(H_{w}+H_{p_{2}}\right) x_{c}^{\prime \prime}+\frac{1}{2} w_{c}\right\} \theta_{2} \\
&=
\end{aligned}
$$

上式の第 $1 \sim 3$ 式で示された補剛桁の鉛直方向, 水平横 方向およびねじりのつり合い式は， $I_{\omega y}=0$ すなわちせ ん断中心と重心が合致する場合については既往の島田 ${ }^{11}$ および倉西 ${ }^{12)}$ の式と合致するものである.ケーブルの水 平横方向のつり合い式については基礎方程式が異なり, 倉西の式では次のように与えられる ${ }^{12)}$.

$$
\left.\begin{array}{l}
\left(H_{w}+H_{p_{1}}\right) \bar{v}_{1}^{\prime \prime}+S_{1} \theta_{1}=-\frac{1}{2} p_{c} \\
\left(H_{w}+H_{p_{2}}\right) \bar{v}_{2}^{\prime \prime}+S_{2} \theta_{2}=-\frac{1}{2} p_{c}
\end{array}\right\}
$$

\section{ここに, $S_{1}, S_{2}$ : ハンガーの張力}

以上の結果を本法の基礎方程式と比較すれば次のとお りである. 寸なわち, 式 (28) の第 4, 5 式を第 3,4 式 に代入すれば $\kappa=0$ とおいた場合の本法と同様の基礎式 になる・しかし $\theta_{1}, \theta_{2}$ の係数が異なる.たとえば,式 (28) の第 4 式の係数は既知のケーブルの鉛直方向の力のつり 合い式を用いて次のように変形される.

$$
\begin{aligned}
-\{ & \left.\left(H_{w}+H_{p_{1}}\right) x_{c}{ }^{\prime \prime}+\frac{1}{2} w_{c}\right\} \\
= & -\left(H_{w}+H_{p_{1}}\right)\left(x_{c}^{\prime \prime}+u^{\prime \prime}-\frac{b}{2} \varphi^{\prime \prime}\right) \\
& -\frac{1}{2} w_{c}+\left(H_{w}+H_{p_{1}}\right)\left(u^{\prime \prime}-\frac{b}{2} \varphi^{\prime \prime}\right) \\
= & S_{1}+\left(H_{w}+H_{p_{1}}\right)\left(u^{\prime \prime}-\frac{b}{2} \varphi^{\prime \prime}\right) \cdots \cdots .
\end{aligned}
$$

上式の第 2 項は, 活荷重による変位 $\left(u-\frac{b}{2} \varphi\right)$ がケーブ ルの初期形状 $x_{c}$ に比べて通常十分に小さく無視できる ことを考慮するとき，式（28）の第 4,5 式は実質的に 式（29）に合致するものである. 本法では直接ハンガー 張力を求めることが不可能なため既知の補剛析の鉛直方 向の荷重と自重を用いて表わしたが，これは倉西の式に おいて, $S_{1}=\frac{1}{2}\left(p_{v}+w_{t}\right)\left(1+\frac{2 a}{b} \varphi\right)$ とおいて微小量 を無視した場合と同じである.このほかに $S_{1}$ には補剛 桁の鉛㨁方向の曲げによる抗力の項が含まれるはずであ るが, 長支間吊橋では補剛桁の重力の項に比較してはる かに小さいために $S_{1}$ は $\frac{1}{2}\left(p_{v}+w_{t}\right)$ で近似的に表わ すことができる.よって本法の基礎方程式は同じ結果を 与えるものと予想される.

\section{（2）非連成法との比較}

鉛直変位, 水平横変位およびねじりの各変形が独立に 生ずるという仮定のもとに誘導された従来の基礎方程式 と比較すれば次のとおりである.

本題の基礎方程式（20）の第1 1 式の鉛直方向のつり合 い式において, ねじりの項を無視し, かつ $H_{p_{1}}=H_{p_{2}}=$ $H_{p}$ とおけば,

$$
E I_{v} u^{(4)}-2\left(H_{w}+H_{p}\right) u^{\prime \prime}-2 H_{p} x_{c}{ }^{\prime \prime}=p_{v}
$$

が得られ, 接度理論と同一の基礎方程式になる. また, 式 (20) の第 2,3 式のねじりおよび水平横方向のつり 合い式において, ハンガーの傾斜角 $\theta$ を無視し, かつ $H_{p_{1}}=-H_{p_{2}}=H_{p}$ とおけば次式が得られる.

$$
\begin{aligned}
& E I_{\omega} \varphi^{(4)}-\left(G J+\frac{b^{2}}{2} H_{w}\right) \varphi^{\prime \prime} \\
&+H_{p} b x_{c}{ }^{\prime \prime}-E I_{\omega y} v^{(4)}=m_{t}, \\
& E I_{h} v^{(4)}-E I_{\omega y} \varphi^{(4)}=p_{h}
\end{aligned}
$$

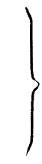


上式は文献 2）に示されたねじりおよび水平横変位連成 振動の基礎方程式において慣性力を無視した場合と合致 する. また，本法の基礎方程式の第 3,4 おょよび 5 式に おいて, $\bar{v}_{1}=\bar{v}_{2}=\bar{v}, H_{p_{1}}=H_{p_{2}}=0, p_{v}=0, a=0$ および $\varphi=0$ とし, 適合条件式を用いて ハンガーの傾斜角を消 去すれば次式が得られる.

$$
\left.\begin{array}{l}
E I_{h} v^{(4)}+\frac{1}{h}(v-\bar{v}) w_{t}=p_{h} \\
2 H_{w} \bar{v}^{\prime \prime}+\frac{1}{h}(v-\bar{v}) w_{t}=-p_{c}
\end{array}\right\}
$$

上式は文献 2) に示される風の抗力による水平横変位を 求めるための基礎方程式と一致する. 以上から, 本題の 基礎方程式は従来の非連成法の基礎方程式をすべて含む ことが明らかになった。

\section{9. 基礎方程式の簡略化}

吊橋のケーブルに作用する水平横荷重は風荷重である から左右のケーブルの水平横変位を等しい $\left(\bar{v}_{1}=\bar{v}_{2}=\bar{v}\right)$ とおくことができ，したがって，左右のハンガーの傾斜 角は $\theta_{1}=\theta_{2}=\theta$ となる. また, ケーブルの形状が式 (4) のように表わされることを考虑すれば，本題の基礎方程 式は次のように簡略化される.

$$
\begin{aligned}
E I_{v} u^{(4)} & -\left(2 H_{w}+H_{p_{1}}+H_{p_{2}}\right) u^{\prime \prime} \\
+ & \left(H_{p_{1}}-H_{p_{2}}\right) \frac{b}{2} \varphi^{\prime \prime}=p_{v}-\left(H_{p_{1}}+H_{p_{2}}\right) \frac{8}{l^{2}} f, \\
\left(H_{p_{1}}-H_{p_{2}}\right) \frac{b}{2} u^{\prime \prime}+E I_{\omega} \varphi^{(4)}-\left(G J-2 \kappa E I_{y \omega}\right) \varphi^{\prime \prime} & \\
- & \left(2 H_{w}+H_{p_{1}}+H_{p^{2}}\right) \frac{b^{2}}{4} \varphi^{\prime \prime}+E I_{h^{2}} \kappa^{2} \varphi \\
& -E\left(I_{y \omega}-\kappa I_{\omega}\right) v^{(4)}+\kappa\left(E \kappa I_{y \omega}-E I_{h}-G J\right) v^{\prime \prime} \\
& +a\left(p_{v}+w_{t}\right) \theta=m_{t}+\left(H_{p_{1}}-H_{p_{2}}\right) \frac{4}{l^{2}} f b, \\
-E\left(I_{y \omega}-\kappa I_{\omega}\right) \varphi^{(4)}+\kappa\left(E \kappa I_{y \omega}-E I_{h}-G J\right) \varphi^{\prime \prime} & +E\left(I_{h}-2 I_{y \omega} \kappa+I_{\omega} \kappa^{2}\right) v^{(4)} \\
& -G J \kappa^{2} v^{\prime \prime}+\left(p_{v}+w_{t}\right) \theta=p_{h}, \\
\left(2 H_{w}+\right. & \left.H H_{p_{1}}+H_{p_{2}}\right) \bar{v}^{\prime \prime}+\left(p_{v}+w_{t}\right) \theta=-p_{c}
\end{aligned}
$$

ここに, $h \theta=v-\bar{v}+a \varphi$

式 (34) は本題の連成を考慮した吊橋の解析のための 基礎方程式である. 第 1,2 式の鉛直方向および ねじり のつり合い式の左辺の係数項に式 (27) に示すケーブル の変位 $\bar{u}$ および $\bar{v}$ によって決定されるケーブルの活荷 重水平張力 $H_{p i}$ の項が含まれる.このために, 基礎方 程式の第 1,2 式は 2 次および 3 次の 幾何学的な 原因に よる非線形項をもつ.したがって, 吊橋の全体の剛性が 変形に依存して変化する.すなわち, ケーブルの正の 鉛直変位 $\bar{u}$ に対しては式（27）からケーブルの正の活
荷重水平張力 $H_{p i}$ が算定される.これによって, 倸数 $\left(2 H_{w}+H_{p 1}+H_{p 2}\right)$ は増加するために 吊橋の剛性が増 大寸る. 逆に負の変位 $\bar{u}$ に対する負の活荷重水平張力 によって係数 $\left(2 H_{w}+H_{p_{1}}+H_{p_{2}}\right)$ は減少するために吊 橋の剛性が減少する.ケーブルの水平横方向の変位 $\bar{v} に$ よって正のケーブルの活荷重水平張力が常に生ずるため に, 吊橋の剛性が高められる.また, 式 (34) の第 2 式 のねじりの式の左辺においてケーブルの活荷重水平張力 のほかに補剛桁の初期曲率 $\kappa$ および補剛桁の重心と上 弦材中心との距離 $a$ が水平横変位、と㸚じり $\varphi$ の連 成の原因となっている.

\section{0．風荷重を受ける吊橋の変形と応力}

\section{（1）解 法}

誘導した基礎方程式を用いて Fig. 1 に示す 3 径間単 純吊橋を対象に 3 分力を考慮した一様分布の風荷重を受 ける場合の静的挙動を解析する．なお，風荷重はその大 きさが変形とともに変化する非保存系であるために厳密 には保存系として誘導した基礎方程式には適用できない が，静的問題では第 1 近似值として有効であると考えら れる. Fig. 4 は関門橋の 2 次元模型による風洞実験に よって求められた抗力, 揚力および空力モーメントの各 係数である ${ }^{17)}$. 迎え角 $\alpha$ につて各係数は次のように線 形化される。

$$
\left.\begin{array}{l}
\bar{C}_{D}=C_{D}(\alpha)+\left(\frac{d C_{D}}{d \alpha}\right)_{\alpha} \varphi, \\
\bar{C}_{L}=C_{L}+\left(\frac{d C_{L}}{d \alpha}\right)_{\alpha} \varphi, \\
\bar{C}_{M}=C_{M}(\alpha)+\left(\frac{d C_{M}}{d \alpha}\right)_{\alpha} \varphi
\end{array}\right\}
$$

したがって, 風荷重に起因する吊橋の作用活荷重は, 次

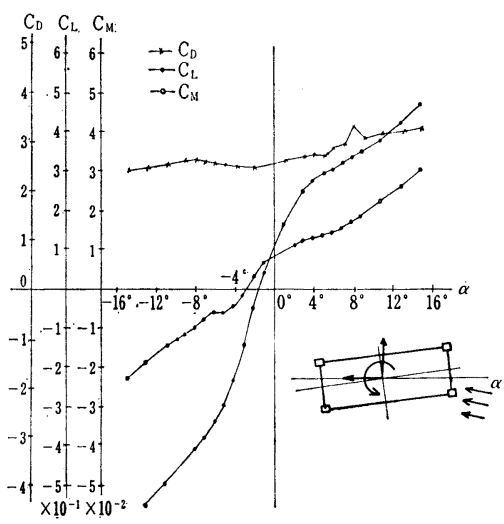

Fig. 4 Relation between components, $C_{L}, C_{M}$ and $C_{D}$ due to wind loads and angle of attack $\alpha$ 
のように表わすことができる.

$$
\begin{aligned}
& p_{v}=-0.5 \rho V^{2} \bar{C}_{L} A_{L}=-L_{t}-L_{x}{ }^{*} \varphi, \\
& p_{h}=0.5 \rho V^{2} \bar{C}_{D} A_{D}=D_{t}+D_{t}{ }^{*} \varphi, \\
& m_{t}=0.5 \rho V^{2} \bar{C}_{M} A_{L}=M_{t}+M_{t}{ }^{*} \varphi, \\
& p_{c}=0.5 \rho V^{2} A_{D c}=D_{c}
\end{aligned}
$$

ここに,

$$
\begin{aligned}
& L_{t}=0.5 \rho V^{2} C_{L} A_{L}, L_{t}^{*}=0.5 \rho V^{2}\left(\frac{d C_{L}}{d \alpha}\right)_{\alpha} A_{L}, \\
& D_{t}=0.5 \rho V^{2} C_{D} A_{D}, D_{t}^{*}=0.5 \rho V^{2}\left(\frac{d C_{D}}{d \alpha}\right)_{\alpha} A_{D}, \\
& M_{t}=0.5 \rho V^{2} C_{M} A_{L}, M_{t}^{*}=0.5 \rho V^{2}\left(\frac{d C_{M}}{d \alpha}\right)_{\alpha} A_{L}
\end{aligned}
$$

吊橋のケーブルの形は中央径間でサグ $f$, 側径間でサグ $f_{1}$ なる放物線とし, また, 中央径間の補剛桁の縦断曲 線がサグ $f *$ なる放物線で与えられ，側径間の補剛桁は 高低差 $h_{1}$ なる直線であるとすれば中央径間および側径 間のハンガー長は次のとおりである.

$$
\begin{aligned}
& h(z)=h_{T}-\left(x_{c}+x^{*}\right) \\
& =4\left(f+f^{*}\right) \frac{z^{2}}{l^{2}}-4\left(f+f^{*}\right) \frac{z}{l}+h_{T}, \\
& \left\{E I_{v}\left(\frac{n \pi}{l}\right)^{4}+\left(2 H_{w}+H_{p_{1}}+H_{p_{2}}\right)\left(\frac{n \pi}{l}\right)^{2}\right\} a_{n}+\left\{-\frac{b}{2}\left(H_{p_{1}}-H_{p_{2}}\right)\left(\frac{n \pi}{l}\right)^{2}+L_{t} *\right\} b_{n} \\
& =-\frac{2}{n \pi}\left\{1-(-1)^{n}\right\}\left\{L_{t}+\left(H_{p_{1}}+H_{p_{2}}\right) \frac{8 f}{l^{2}}\right\}, \\
& -\frac{b}{2}\left(H_{p i}-H_{p_{2}}\right)\left(\frac{n \pi}{l}\right)^{2} a_{n}+\left[E I_{\omega}\left(\frac{n \pi}{l}\right)^{4}+\left\{G J-2 \kappa E I_{y \omega}+\frac{b^{2}}{4}\left(2 H_{w}+H_{p 1}+H_{p 2}\right)\right\}\left(\frac{n \pi}{l}\right)^{2}\right. \\
& \left.+E I_{h} \kappa^{2}-M_{t}{ }^{*}\right] b_{n}+\left\{E\left(\kappa I_{\omega}-I_{y_{\omega}}\right)\left(\frac{n \pi}{l}\right)^{4}+\kappa\left(G J+E I_{h}-E \kappa I_{y_{\omega}}\right)\left(\frac{n \pi}{l}\right)^{2}\right\} c_{n}-a\left(L_{t}-w_{t}\right) e_{n} \\
& =\frac{2}{n \pi}\left\{1-(-1)^{n}\right\}\left\{M_{t}+\left(H_{p 1}-H_{p_{2}}\right) \frac{4 f l}{l^{2}}\right\}, \\
& \left\{-E\left(I_{y_{\omega}}-I_{\omega} \kappa\right)\left(\frac{n \pi}{l}\right)^{4}+\kappa\left(G J+E I_{h}-I_{y \omega} \kappa\right)\left(\frac{n \pi}{l}\right)^{2}-D_{t^{*}}\right\} b_{n}+\left\{E\left(I_{h}-2 I_{y \omega} \kappa+I_{\omega} \kappa^{2}\right)\left(\frac{n \pi}{l}\right)^{4}\right. \\
& \left.+G J_{\kappa^{2}}\left(\frac{n \pi}{l}\right)^{2}\right\} c_{n}-\left(L_{t}-w_{t}\right) e_{n}=\frac{2}{n \pi}\left\{1-(-1)^{n}\right\} D_{t}, \\
& -\left(2 H_{w}+H_{p 1}+H_{p 2}\right)\left(\frac{n \pi}{l}\right)^{2} d_{n}-\left(L_{t}-w_{t}\right) e_{n}=-\frac{2}{n \pi}\left\{1-(-1)^{n}\right\} D_{c}, \\
& a b_{n}+c_{n}-d_{n}-\left\{h_{a}-2\left(f+f^{*}\right)\left(\frac{1}{3}+\frac{1}{n^{2} \pi^{2}}\right)\right\} e_{n}=\frac{32\left(f+f^{*}\right)}{\pi^{2}} \sum_{m \neq n} \frac{m \cdot n}{\left(m^{2}-n^{2}\right)^{2}} e_{m}
\end{aligned}
$$

他方, 吊橋の塔が変形しないものとすれば, 補剛析およ びケーブルの境界条件が次のように与えられる.

$$
\left.\begin{array}{l}
u(0)=u(l)=0, u^{\prime \prime}(0)=u^{\prime \prime}(l)=0, \\
\varphi(0)=\varphi(l)=0, \varphi^{\prime \prime}(0)=\varphi^{\prime \prime}(l)=0, \\
v(0)=v(l)=0, v^{\prime \prime}(0)=v^{\prime \prime}(l)=0, \\
\bar{v}(0)=\bar{v}(l)=0, \theta(0)=\theta(l)=0
\end{array}\right\}
$$

上記の境界条件を満足する各変位を次のようにフーリエ

$$
\begin{aligned}
& u(z)=\sum_{n=1}^{\infty} a_{n} \sin n \pi \xi, \varphi(z)=\sum_{n=1}^{\infty} b_{n} \sin n \pi \xi, \\
& v(z)=\sum_{n=1}^{\infty} c_{n} \sin n \pi \xi, \bar{v}(z)=\sum_{n=1}^{\infty} d_{n} \sin n \pi \xi, \\
& \theta(z)=\sum_{n=1}^{\infty} e_{n} \sin n \pi \xi, \xi=z / l
\end{aligned}
$$

なお，側径間については上記の連立方程式にサフィクス “1”をつけ，かつ $\kappa=0$ とおけばよい，ただし，式 (40) の第 5 式は次のように書き改められる.

$$
\begin{aligned}
& a b_{n 1}+c_{n 1}-d_{n 1}-\left\{h_{a}-2 f_{1}\right. \\
& \left.\quad \times\left(\frac{1}{3}+\frac{1}{n^{2} \pi^{2}}-\frac{h_{1}}{4 f_{1}}+\frac{f_{1}^{*}}{4 f_{1}}\right)\right\} e_{n 1} \\
& =\frac{16 f_{1}}{\pi^{2}} \sum_{m \neq n} \frac{m \cdot n}{\left(m^{2}-n^{2}\right)^{2}}\left[1+(-1)^{m+n}\right. \\
& \left.-\left(\frac{f_{1}^{*}}{4 f_{1}}-\frac{h_{1}}{4 f_{1}}\right)\left\{(-1)^{m+n}-1\right\}\right] e_{m 1}
\end{aligned}
$$

同様に式（39）を式（27）に代入すれば，ケーブル方程 式が次のように書き改められる.

$$
\begin{aligned}
& H_{p i}=\frac{E_{c} A_{c}}{L_{E}}\left\{\frac{16 f}{\pi l} \sum_{n=1}^{\infty} \frac{1}{n}\left(a_{n} \mp \frac{b}{2} b_{n}\right)\right. \\
& +\frac{32 f_{1}}{\pi l_{1}} \sum_{n=1}^{\infty} \frac{1}{n}\left(a_{n 1} \mp \frac{b}{2} b_{n 1}\right) \\
& +\frac{\pi^{2}}{4 l} \sum_{n=1}^{\infty} n^{2} d n^{2}+\frac{\pi^{2}}{2 l_{1}} \sum_{n=1}^{\infty} n^{2} d_{n 1}{ }^{2} \\
& \left.-\alpha_{T} \Delta T L_{T}\right\}
\end{aligned}
$$


式（39）を式（18）に代入すれば, 補剛桁に作用する各断面力が次のように得られる.

$$
\begin{aligned}
M_{h}= & E \sum_{n=1}^{\infty}\left[I_{h}\left\{\kappa b_{n}+\left(\frac{n \pi}{l}\right)^{2} c_{n}\right\}-I_{y_{\omega}}\left(b_{n}+\kappa c_{n}\right)\left(\frac{n \pi}{l}\right)^{2}\right] \sin n \pi \xi, \\
M_{v}= & E I_{v} \sum_{n=1}^{\infty} a_{n}\left(\frac{n \pi}{l}\right)^{2} \sin n \pi \xi, \\
M_{\omega}= & E \sum_{n=1}^{\infty}\left[I_{y \omega}\left\{\kappa b_{n}+\left(\frac{n \pi}{l}\right)^{2} c_{n}\right\}-I_{\omega}\left(b_{n}+\kappa c_{n}\right)\left(\frac{n \pi}{l}\right)^{2}\right] \sin n \pi \xi, \\
M_{s}= & G J \sum_{n=1}^{\infty}\left(b_{n}+\kappa c_{n}\right)\left(\frac{n \pi}{l}\right) \cos n \pi \xi, \\
T= & \sum_{n=1}^{\infty}\left[E\left[-I_{y \omega}\left\{\kappa b_{n}+\left(\frac{n \pi}{l}\right)^{2} c_{n}\right\}\left(\frac{n \pi}{l}\right)+I_{\omega}\left(b_{n}+\kappa c_{n}\right)\left(\frac{n \pi}{l}\right)^{3}\right]+G J\left(b_{n}+\kappa c_{n}\right)\left(\frac{n \pi}{l}\right)\right] \cos n \pi \xi, \\
P_{v}= & E I_{v} \sum_{n=1}^{\infty}\left(\frac{n \pi}{l}\right)^{3} a_{n} \cos n \pi \xi, \\
P_{h}= & \sum_{n=1}^{\infty}\left[E\left\{\left(I_{h}-2 I_{y \omega} \kappa+I_{\omega} \kappa^{2}\right)\left(\frac{n \pi}{l}\right)^{2} c_{n}+\left(\kappa I_{\omega}-I_{y \omega}\right)\left(\frac{n \pi}{l}\right)^{2} b_{n}+\kappa\left(I_{h}-I_{y \omega} \kappa\right) b_{n}\right\}\left(\frac{n \pi}{l}\right)\right. \\
& \left.+G J \kappa\left(b_{n}+\kappa c_{n}\right)\left(\frac{n \pi}{l}\right)\right] \cos n \pi \xi
\end{aligned}
$$

式 (42) で求められるケーブル $i$ の活荷重水平張力 $H_{p i}$ は補剛桁の変位によって定まるが, 式 (40) の連立方程 式の係数項にこれらの項が多く含まれるために計算は一 種の試算による収束計算となる. なお, 初期値は次に示 寸数值計算によってケーブルの活荷重水平張力 $H_{p_{1}}$, $H_{p 2}$ は吊橋の鉛直変位を打ち消すように作用すること が明らかになったので, 式 (40) の第 1 式の右辺を零と する $H_{p_{1}}=H_{p_{2}}=-L_{t} \frac{l^{2}}{16 f}$ を用いて計算をすすめる ことが可能である.

本論文では, 具体的な吊橋の風荷重特性計算のため, 次の諸元を採用したが以下はその演算結果をもとに考察 をすすめることにする.

$$
\begin{aligned}
& l=703.5 \mathrm{~m}, \quad l_{1}=167.75 \mathrm{~m}, \\
& l_{2}=17.667 \mathrm{~m}, \quad f=64 \mathrm{~m}, \\
& f_{1}=3.906 \mathrm{~m}, \quad h_{T}=69.119 \mathrm{~m}, \\
& h=69.119 \mathrm{~m}, \quad f^{*}=3.517 \mathrm{~m}, \\
& h_{a}=1.25 \mathrm{~m}, \quad d=9 \mathrm{~m}, \\
& b=29 \mathrm{~m}, \quad a=1.635 \mathrm{~m} \text {, } \\
& e=0.0 \mathrm{~m}, \quad L_{E}=1216.056 \mathrm{~m} \text {, } \\
& L_{T}=1234.588 \mathrm{~m}, \quad I_{v}=3.440 \mathrm{~m}^{4} / \text { Bridge, } \\
& I_{v_{1}}=2.582 \mathrm{~m}^{4} / \text { Bridge }, \quad I_{h}=33.67 \mathrm{~m}^{4} / \text { Bridge }, \\
& I_{h 1}=26.912 \mathrm{~m}^{4} / \text { Bridge }, \quad J=3.517 \mathrm{~m}^{4} / \text { Bridge }, \\
& J_{1}=3.000 \mathrm{~m}^{4} / \text { Bridge, } \quad I_{\omega}=729.0 \mathrm{~m}^{6} / \text { Bridge, } \\
& I_{\omega 1}=600 \mathrm{~m}^{6} / \text { Bridge }, \quad I_{y_{\omega}}=0.0 \mathrm{~m}^{5} / \text { Bridge, } \\
& H_{w}=11682.6 \mathrm{t} / \text { Cable, } w_{t}=19.04 \mathrm{t} / \mathrm{m} \text {, } \\
& w_{t_{1}}=20.814 \mathrm{t} / \mathrm{m}, \quad w_{c}=5.132 \mathrm{t} / \mathrm{m}, \\
& \Delta T=0.0^{\circ} \mathrm{C}, \quad \kappa=5.85 \times 10^{-5} / \mathrm{m}, \\
& E=2.1 \times 10^{7} \mathrm{t} / \mathrm{m}^{2}, \quad E_{c}=2.0 \times 10^{7} \mathrm{t} / \mathrm{m}^{2}, \\
& G=0.81 \times 10^{7} \mathrm{t} / \mathrm{m}^{2}, \quad V=54 \mathrm{~m} / \mathrm{sec}, \\
& \rho=0.125 \mathrm{~kg} \cdot \mathrm{sec}^{2} / \mathrm{m}^{4}, A_{D}=4.116 \mathrm{~m}^{2}, \\
& A_{L}=23.2 \mathrm{~m}^{2}, \quad A_{D c}=0.5592 \mathrm{~m}^{2} / \text { Bridge, }
\end{aligned}
$$

$$
A_{c}=0.2796 \mathrm{~m}^{2}, \quad r_{0}=45^{\circ}, \quad r_{1}=27^{\circ} 07^{\prime}
$$

\section{（2）従来の解法との比較および解の収束}

従来の風荷重による吊橋の変形と応力を解析する式は 式 (33) であるが, 伊藤) は式 (33) を解析的に解くため に, 変位 仮定のうえ, 両辺に $h(z)$ をかけてガラーキン法を適用 して未定定数を求めるための連立方程式を誘導した. 本 法と伊藤の方法を比較するために, 式(40)加式(33)に 対応する項のみを残した場合について, 吊橋の中央径間 中点の補剛桁およびケーブルの水平横変位 $v, \bar{v}$ の収束 状況を Fig. 5 に示す. 図において横軸はフーリエ級数 の項数 $n$ を, 縦軸は補剛桁およびケーブルの水平横変位 $v, \bar{v}$ を示す. 本例では吊橋の形状および荷重が左右対 称のために, 変位も左右対称となる. したがって, 級数 の収束計算には奇数項 $n=1,3,5 \cdots$ を採用すればよい. 本法の級数の収束はきわめて早く 3 項程度で完全に収束 する.これに対して伊藤の方法は収束が遅くしかも振動 していることがわかる.このため, 本法と同程度の解を らるためには 3 倍以上の項数を心要とする. 本法では八 ンガーの傾斜角 $\theta$ を末知数に加えたために式が伊藤の 方法に比して1個増加したが，このことにより方程式の 形がかえって簡単となり，しかもかつ収束がきわめて早 〈数值解析上本法が有利であるといえる. なお, 伊藤の 方法の解の収束が遅い原因は Fig. 1 亿示寸ような変位 を仮定した $\sin$ の波形と大きく異なった ハンガー長 $h$ の項が式の両辺に数多く含まれることによるものであ る. 他の変位成分については相対誤差が $0.1 \%$ の収 束判定值に対して 鉛直変位は 5 項 $(n=9)$, ねじりは 7 項 $(n=13)$ 程度で収束するが, 補剛桁の中央部で大き な值となるハンガーの傾斜角は収束が やや遅く 13 項 


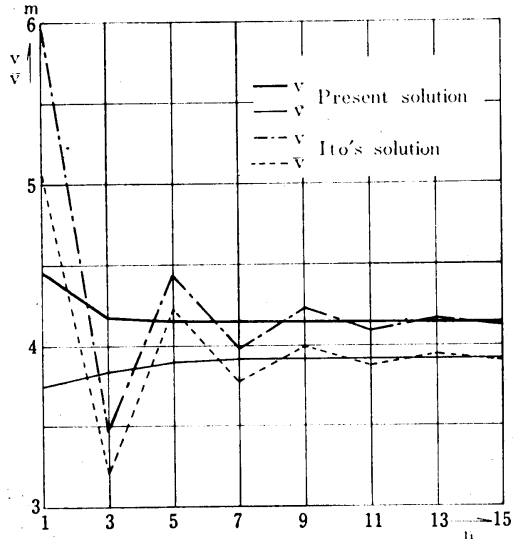

Fig. 5. Convergence of horizontal displacements, $v$ and $\bar{v}$, of the stiffening truss and cable

$(n=25)$ 程度必要である. 断面力のうち曲げモーメント $M_{h}$ は 4 項 $(n=7), M_{v}$ は 9 項 $(n=17)$, 曲げねじりモ 一メント $M_{\omega}$ は 10 項 $(n=19)$ で十分収束するが, 補剛 桁の端部で最大となるせん断力 $P_{h}, P_{v}$ および合ねじ りモーメント $T$ の収束はきわめて遅く, 35 項 $(n=69)$ 程度必要とした.

\section{（3） ケーブルの活荷重水平張力 $\boldsymbol{H}_{p i}$ の影䇾}

緒言で述べたように従来の吊橋の解析ではケーブル方 程式には鉛直変位のみが考虑され，水平横変位の影響は 無視されている.これはケーブルが水平横方向にサグを 持たないためであるが, 風の抗力による水平横変位が大 きい場合には検討の余地がある. そこで 3 分力を考虑し た風荷重について,

（a） 従来のケーブル方程式を用いた場合

（b）ケーブルの水平横変位をも考虑したケーブル方 程式を用いた場合

（d）ケーブルの活 荷 重 水平張力を無視した場 合 $\left(H_{p_{1}}=H_{p_{2}}=0.0\right)$

荷重として抗力のみを残し, 補剛桁の図心にハンガー が取りつけられた状態 $(a=0)$ について,

(c) ケーブルの水平横変位をも考慮したケーブル方 程式を用いた場合

（e），ケーブルの活荷重水平張力を無視した場合5),8) の 5 ケースについてケーブルの活荷重水平張力の影響を 検討した. 初期曲率 $\kappa$ の影響を無視し, 風の迎え角 $\alpha$ $=0^{\circ}, 4^{\circ},-4^{\circ}$, の各ケースについて, ケーブルの活荷重 水平張力 $H_{p_{1}}, H_{p_{2}}$ および中央径間の中点の変位 $u, \varphi$, $v, \bar{v}, \theta$ を示せば Table 1 のとおりである. 表より明 らかなように, 補剛桁およびケーブルの水平横変位 $v$, $\bar{v}$ についてはケーブルの 活荷重水平張力 $H_{p_{1}}, H_{p_{2}}$ に よる全水平張力 $\left(2 H_{w}+H_{p_{1}}+H_{p_{2}}\right)$ の変化に伴って従 来の解析結果 (e) から $3 \sim 12 \mathrm{~cm}$ 程度変化するが, $4 \mathrm{~m}$
程度の水平横変位に対する割合は小さい. したがって, 水平横変位については吊橋の荷重として抗力のみを用い てケーブルの活荷重水平張力を無視する線形解析で十分 であるといえる.

Table 1 に示すように補剛桁の鉛直変位 $u$ について は, (d) のケーブルの活荷重水平張力の変化を無視する 場合には揚力によって 1 3 m 程度変位するが, (a) の ケーブルの鉛直変位のみを考虑したケーブル方程式を用 いると，補剛桁の鉛直変位は揚力の正負に無関係に（d) の場合の約 $8 \%$ 程度に減少し, ケーブルの活荷重水平 張力は鉛直変位にきわめて大きな影響を及ぼす結果とな る. なお, ケーブルの活荷重水平張力 $H_{p i}$ の大きさは 死荷重水平張力 $H_{w}=\left(w_{t}+w_{c}\right) \frac{l^{2}}{16 f}=11682.6 \mathrm{t}$ に比 ベて 最大約 $4.7 \%$ の大きさである.この理由はケーブ ルの活荷重水平張力が式（40）の第 1 式の右辺の \{ \}の 中 $L_{t}+\left(H_{p_{1}}+H_{p_{2}}\right) \frac{8 f}{l^{2}}$ を零にするように作用するこ とを意味するものである. したがって，この性澌を利用 すれば，吊橋のねじりは小さいから， $H_{p 1}=H_{p 2}$ とおい て $\underset{(i=1,2)}{H_{p i}}=-L_{t} \frac{l^{2}}{16 f}$ から容易にこれらの初期值を推定 することができる*.

（b）のケーブルの水平横変位をも考虑したケーブル方

Table 1 Effect of the horizontal component $H_{p i}$ of the tensile force in cable on displacements

case $1 \alpha=0^{\circ}$

\begin{tabular}{lc|r|r|c|c|l}
\hline & & $(\mathrm{a})$ & $(\mathrm{b})$ & $(\mathrm{c})$ & $(\mathrm{d})$ & $(\mathrm{e})$ \\
\hline$H_{p 1}$ & $(\mathrm{t})$ & -182.18 & -163.79 & 18.34 & 0.0 & 0.0 \\
$H_{p 2}$ & $(\mathrm{t})$ & -173.67 & -155.13 & 18.34 & 0.0 & 0.0 \\
$u$ & $(\mathrm{~m})$ & -0.080 & -0.179 & -0.095 & -1.010 & 0.0 \\
$\phi \times 10^{-3}$ (rad.) & -0.307 & -0.314 & 0.0 & -0.100 & 0.0 \\
$v$ & $(\mathrm{~m})$ & 4.178 & 4.174 & 4.135 & 4.143 & 4.137 \\
$\bar{v}$ & (m) & 3.958 & 3.954 & 3.918 & 3.920 & 3.922 \\
$\theta$ & (rad.) & 0.137 & 0.138 & 0.136 & 0.139 & 0.135 \\
\hline
\end{tabular}

case $2 \alpha=4^{\circ}$

\begin{tabular}{lc|r|r|c|c|l}
\hline & & $(\mathrm{a})$ & $(\mathrm{b})$ & $(\mathrm{c})$ & $(\mathrm{d})$ & $(\mathrm{e})$ \\
\hline$H_{p 1}$ & $(\mathrm{t})$ & -544.51 & -524.27 & 19.33 & 0.0 & 0.0 \\
$H_{p 2}$ & $(\mathrm{t})$ & -478.03 & -458.32 & 19.35 & 0.0 & 0.0 \\
$u$ & $(\mathrm{~m})$ & -0.232 & -0.339 & -0.101 & -2.902 & 0.0 \\
$\phi \times 10^{-3}$ (rad.) & 0.559 & 0.558 & 0.0 & 2.290 & 0.0 \\
$v$ & (m) & 4.375 & 4.371 & 4.252 & 4.273 & 4.256 \\
$\bar{v}$ & (m) & 4.141 & 4.137 & 4.027 & 4.034 & 4.031 \\
$\theta$ & (rad.) & 0.147 & 0.147 & 0.140 & 0.151 & 0.140 \\
\hline \multicolumn{7}{r}{}
\end{tabular}

case $3 \alpha=-4^{\circ}$

\begin{tabular}{lc|r|r|c|c|l}
\hline & & $(\mathrm{a})$ & $(\mathrm{b})$ & $(\mathrm{c})$ & $(\mathrm{d})$ & $(\mathrm{e})$ \\
\hline$H_{p 1}$ & $(\mathrm{t})$ & 480.48 & 497.08 & 16.89 & 0.0 & 0.0 \\
$H_{p 2}$ & $(\mathrm{t})$ & 375.30 & 392.14 & 16.88 & 0.0 & 0.0 \\
$u$ & (m) & 0.198 & 0.114 & -0.088 & 2.539 & 0.0 \\
$\phi \times 10^{-3}$ (rad.) & -2.014 & -2.027 & 0.0 & -4.960 & 0.0 \\
$v$ & (m) & 3.884 & 3.882 & 3.964 & 3.971 & 3.967 \\
$\bar{v}$ & (m) & 3.682 & 3.679 & 3.758 & 3.769 & 3.761 \\
$\theta$ & (rad.) & 0.124 & 0.124 & 0.128 & 0.121 & 0.128 \\
\hline
\end{tabular}


程式を用いると，補剛析は（a）の場合よりも $10 \mathrm{~cm}$ 程 度上方に変位することになる．径間中央で $4 \mathrm{~m}$ 程度の sin 波形で表わされる水平横変位によってケーブルには $300 \mathrm{t}$ 程度の付加引張水平張力が 生ずるものと予想され たが，Table 1 (c) に示すように 17 18 $\mathrm{t}$ 程度の大き さとなった。これはケーブルが水平横方向に純粋に移動 することが不可能で，塔頂を結ぶ水平線上を中心とする 円弧を描く振子状の動きを起こすことを意味するものと 考えられる. Table 1 に示すようにケーブルの活荷重 水平張力 $H_{p 1}, H_{p 2}$ および 鈆直変位 $u$ の (a) の結果 を加え合せたものは（d）の結果にほぼ合致することか ら，(b) の結果の鉛直変位の増加は振子状の動きによる ケーブルおよび補剛桁の水平横変位に連成するものであ ると予想される.この構造特性による鉛直変位は揚力に よる鉛直変位と同程度の大きさになる．したがって，3 分力を考慮した風荷重を受ける吊橋の変形と応力の解析 にあたってはケーブルの水平横変位が活荷重水平張力に 及ぼす影響は無視できない，また，左右のケーブルの活 荷重水平張力の差は補剛桁のねじりに影響を及ぼすが, このことについては次節で一括して取扱う。

以上は補剛桁およびケーブルの諸変位に対する考察で あるが, Table 1 と同じケースに対する $\alpha=0^{\circ}$ の場合 の補剛桁の断面力を示せば Table 2 のとおりである.

Table 2 において, 鉛直方向曲げモーメント $M_{v}$, 水平 方向曲げモーメント $M_{h}$ および曲げねじりモーメント $M_{w}$ は補剛桁中点の諸值に，また，鈶直方向せん断力 $P_{v}$, 水平方向せん断力 $P_{h}$ および合ねじりモーメント $T$ は $z=0$ の原点の諸值にそれぞれ対応するものである.

Table 2 (d) および（a）の比較から明らかなよらに, (a) の $M_{v}$ と $P_{v}$ の大きさは (d) の場合の約 $8 \%$ 程度 の大きさである. したがって,ケーブルの活荷重水平張 力の影響は鉛直変位と同様に補剛桁の鉛直方向の曲げモ ーメントおよびせん断力を減少させる効果をもつ.

\section{（4）初期曲率 $\boldsymbol{\kappa}$ および 補剛桁の 重心と上弦材中心 の距離 $\boldsymbol{a}$ の影響}

式（34）の第 2 式から明らかなように吊橋のねじりと 水平横変位の連成の原因となるものは補剛析の初期曲率 $\kappa$ および補剛桁の重心と上弦材中心との距離 $a$ である. 吊橋のねじりと水平横変位の連成現象を検討するため に，各種の構造特性，荷重の項の組み合せに対するケ一 ブルの活荷重水平張力および中央径間中点の補剛桁およ びケーブルの諸変位を $\alpha=0^{\circ}, 4^{\circ},-4^{\circ}$ に対して求めれ ば Table 3 のとおりである.なお，対象としたケース は次のとおりである.

* なお, 上述のように $H_{p i}$ は $H_{w}$ の約 $4.7 \%$ 程度の大きさ であるために，本研究における非線形項の影響は小さい。
Table 2 Effect of the horizontal component $H_{p i}$ of the tensile force in cable on crosssectional forces

case $1 \quad \alpha=0^{\circ}$

\begin{tabular}{l|r|r|r|r|l}
\hline & \multicolumn{1}{|c|}{$(\mathrm{a})$} & \multicolumn{1}{c|}{$(\mathrm{b})$} & \multicolumn{1}{c|}{$(\mathrm{c})$} & \multicolumn{1}{c|}{$(\mathrm{d})$} & \multicolumn{1}{c}{$(\mathrm{e})$} \\
\hline$M_{v} \times 10^{3}(\mathrm{tm})$ & -0.093 & -0.211 & -0.117 & -1.232 & 0.0 \\
$P_{v} \times 10^{1}(\mathrm{t})$ & -0.175 & -0.372 & -0.196 & -2.086 & 0.0 \\
$M_{h} \times 10^{4}(\mathrm{tm})$ & 5.172 & 5.166 & 5.109 & 5.118 & 5.115 \\
$P_{h} \times 10^{2}(\mathrm{t})$ & 4.259 & 4.257 & 4.234 & 4.244 & 4.279 \\
$M_{w} \times 10^{2}\left(\mathrm{tm}^{2}\right)$ & 9.394 & 9.412 & 0.0 & 8.936 & 0.0 \\
$T \times 10^{2}(\mathrm{tm})$ & 1.384 & 1.379 & 0.0 & 1.746 & 0.0 \\
\hline
\end{tabular}

(a) $H_{p_{1}}=H_{p_{2}}=0.0, \kappa=0, a=0$, ねじり荷重のみ

(b) $H_{p_{1}}=H_{p_{2}}=0, \kappa=0, a \neq 0$, 水平横荷重のみ

(c) $H_{p 1}=H_{p_{2}}=0, \kappa \neq 0, a=0$, 水平横荷重のみ

(d) $H_{p_{1}}=H_{p_{2}}=0, \quad \kappa \neq 0, a \neq 0$, ねじりおよび水平横荷重

(e) $H_{p_{1}} \neq 0, H_{p_{2}} \neq 0, \kappa=0, a=0$, ねじり横荷重のみ

(f) $H_{p_{1}} \neq 0, H_{p_{2}} \neq 0, \kappa=0, a \neq 0$, 水平横荷重のみ

(g) $H_{p_{1}} \neq 0, H_{p_{2}} \neq 0, \kappa \neq 0, a=0$, 水平横荷重のみ

(h) $H_{p_{1}} \neq 0, H_{p_{2}} \neq 0, \kappa \neq 0, a \neq 0$, ねじりおよび水平横荷重

また，(a)〜（h）には従来のケーブル方程式を用いた．

表より明らかなように補剛桁のねじりは，荷重の作用 方向に補剛桁を放じる空力モーメント $m_{t}$ の影響 (a)， 水平横荷重によって生ずる補剛桁とケーブル間の水平横 変位差によって生ずる負のねじりモーメント $a\left(w_{t}\right.$

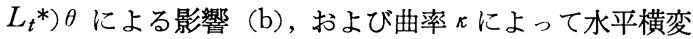
位と連成する負のねじりの影響 (c)，の 3 項から構成さ れる、したがって、ねじりの (a)+(b) + (c) の結果お よび，(e)+(f)+(g) の結果が，それぞれ（d）および (h) の結果にほぼ合致することになる．おのおののねじ りに及ぼす大きさはほぼ同程度であるために, 水平横変 位とねじりを同時に考虑した吊橋の解析ではこれらの影 響は無視できない，曲率 $\kappa$ および水平横変位差によるね ビりは補剛桁を負の方向にねじるから, 正の方向の荷重 のねじりモーメントとは相殺し，負の荷重のねじりモー メントとは加え合せる結果となる. (e)〜 (h) は (a)〜 (d) の各ケースのケーブルの活荷重水平張力を考慮した場合 に対応するもので, 外力の影響は $35 \%$, 水平横変位差 の影響は $44 \%$, 曲率 $\kappa$ の影響は $39 \%$ 程度に小さくな り、ねじりに対しても左右のケーブルの活荷重水平張 力差は構造の剖性を増大させることを意味する。なお 
Table 3 Effect of the initial curvature $\kappa$ and the distance $a$

\begin{tabular}{l}
\multicolumn{2}{c|}{ case $1 \quad \alpha=0^{\circ}$} \\
\hline
\end{tabular}

\begin{tabular}{l} 
case $2 \quad \alpha=4^{\circ}$ \\
\hline
\end{tabular}

\begin{tabular}{l}
\multicolumn{2}{c|}{ case $3 \quad \alpha=-4^{\circ}$} \\
\hline
\end{tabular}

（b）基礎式 (32) を用いて， ねじり荷重のみ

（c）基礎式 (33) を用いて， 水平横荷重のみ

上記のケース (a)，(b)，(c) の 各結果を加え合せたものと, 連成 法の解 (d) の比較を Table 4 に ケーブルの活荷重水平張力および 中央径間中点の諸変位について示 す. 表より補剛桁とケーブルの水 平横変位 $v, \bar{v}$ については, $\kappa=0$ の場合の (3) の項と同様に非連成 法と連成法との差異は小さいこと が確認される．また，(3）と同様 に, 鉛直変位 $u$ についても, 連 成法では抗力による水平横変位と 連成する付加鉛直変位の存在のた めに，非連成法との間にはかなり 差がある・補剛桁のねじり $\varphi$ につ いては, 連成法と非連成法とはま うたく異なった結果を与える.

(4)のねじりの項で述べたよう に, 補剛桁の初期曲率 $\kappa$ と補剛

Table 1 (e) および Table 3 (c) より, 曲率 $\kappa$ の存 在は水平横変位には影響を及ぼさないことがわかる.

Fig. 6 にの影響を考虑した場合としない場合の中央 径間のねじりを示す.

\section{（5）非連成法との比較}

鉛直変位, 水平横変位およびねじりの各変形の連成を 考慮した本法 (連成法) と, 従来のように各変形が独立 に生ずると仮定のうえ, 3 分力を独立に取り扱ら解法

（非連成法）を比較するために，次のような各ケースに ついて計算を行う.

（a）基礎式（31）を用いて，鉛直荷重のみ

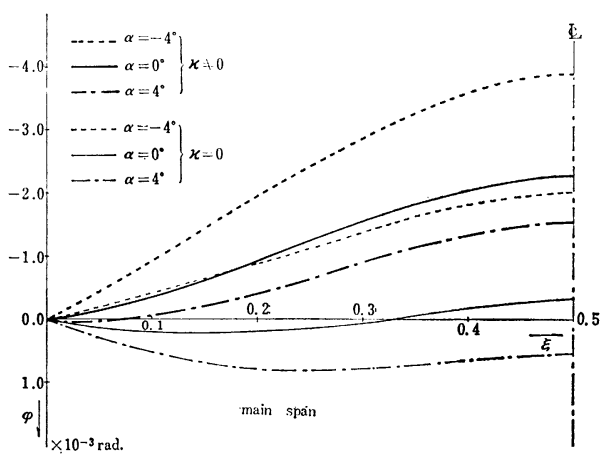

Fig. 6 Effect of the initial curvature $\kappa$ on torsional angle $\phi$ of the main span
析重心と上弦材中心距離 $a$ の影響によって, 補剛桁の 水平横変位に伴ら負のねじりが連成するためである.ケ ーブルの活荷重水平張力についても，連成法には $\kappa$ と $a$ の存在によるねじりとケーブルの水平横変位による久 一ブルの水平張力の増分が含まれるために, 非連成法と は差がある。

\section{（6）風の迎え角の影響}

Fig. 4 の吊橋の空気力曲線の抗力係数 $C_{D}$ は風の迎 え角 $\alpha$ に対してほぼ一定であるが，揚力係数 $C_{L}$ と空 カモーメント係数 $C_{M}$ はかなり変化する. 迎え角 $\alpha$ の 変化 $0^{\circ}, 4^{\circ},-4^{\circ}$ の各ケースにおける吊橋の変形と断 面力を求めれば次のとおりである. Fig. 7 および 8 に 迎え角の変化に伴う吊橋の中央径間および側径間の補剛 桁およびケーブルの水平横変位 $v, \bar{v}$ を示す. 図示のよ らに, $\alpha=4^{\circ}$ の場合がもっとも大きく, ついで $\alpha=0^{\circ}$, $-4^{\circ}$ の順に小さくなるが，その割合は小さい．中央径間 では補剛桁の変位はケーブルの変位より大きいが，逆に 側径間においてはケーブルの方が大きい. 補剛析および ケーブルの変位は側径間においてもほぼ対称である。

Fig. 9 に示すようにハンガーの傾斜角は中央径間では 中央部付近でハンガー長が短いために大きいが，端部に 行くに従って急激に減少する.また，側径間では，ハン ガ一長が短い陸側橋台付近で大きな非対称な形となる. 
したがって, 補剛桁の重力の水平横成分 $\left(w_{t}-L_{t} *\right) \theta$ を 通じて行われる吊橋の風の抗力の補剛桁とケーブルの分 担割合は $\alpha=0^{\circ}$ に対して Fig. 10 に示すように得られ る. Fig. 10 に示した水平横方向の荷重に対する補剛桁 の水平横方向の曲げモーメント $M_{h}$ およびせん断力 $P_{h}$ を Fig. 11 および 12 に示す. Fig. 13 に補刪桁の鉛 直変位 $u$ を示す. 迎え角 $\alpha$ の影響は水平横変位の場合 よりも大きい. ケーブルの水平横変位による付加鉛直変 位を含むために, 補剛析の振子状の動きと同じ上方に揚 力の作用する $\alpha=4^{\circ}$, すなわち風に吹き上げられる場合 がもっとも大きな変形, したがって応力を生ずることに なる. Fig. 14 および 15 に補刪析の鉛直方向の曲げモ 一メント $M_{v}$ およびせん断力 $P_{v}$ を示す. Fig. 16 に 補剛桁のねじり $\varphi$ を示す. 中央径間では曲率 $\kappa$ と $a$ の 影響が同符号で入ってくるために迎え角が負の場合が大 きなねじりを生ずる. 一方, 側径間は曲率はなく, ハン ガーの傾斜角が負で，aの影響は正のねじりを生ずるた めに迎え角が 正の場合が大きなねじりを生ずる. しか し, 主径間に比較してその大きさは小さく, ねじりは迎 え角が負の場合が不利になる. Fig. 17 および 18 に曲 げねじりモーメント $M_{\omega}$ および合ねじりモーメント $T$ を示す. なお, 主構弦材力, 主構斜材力および横構斜材

Table 4 Comparison of the coupling solution with the noncoupling solution

\begin{tabular}{lc|c|c|c|r||r}
\multicolumn{2}{c|}{ case $1 \quad \alpha=0^{\circ}$} \\
\hline & & (a) & (b) & (c) & \multicolumn{1}{c}{$\begin{array}{c}\text { (a) }+(\mathrm{b}) \\
+(\mathrm{c})\end{array}$} & \multicolumn{1}{c}{ (d) } \\
\hline$H_{p 1}$ & $(\mathrm{t})$ & -178.3 & -38.6 & 0.0 & -216.4 & -97.4 \\
$H_{p 2}$ & $(\mathrm{t})$ & -178.3 & 38.6 & 0.0 & -139.2 & -202.0 \\
$u$ & (m) & -0.079 & 0.0 & 0.0 & -0.079 & -0.169 \\
$\phi \times 10^{-3}$ (rad.) & 0.0 & 1.161 & 0.0 & 1.161 & -2.308 \\
$v$ & (m) & 0.0 & 0.0 & 4.138 & 4.138 & 4.177 \\
$\bar{v}$ & (m) & 0.0 & 0.0 & 3.922 & 3.922 & 3.953 \\
$\theta$ & (rad.) & 0.0 & 0.0 & 0.135 & 0.135 & 0.138 \\
\hline
\end{tabular}

\begin{tabular}{lc|c|c|c|c||c}
\multicolumn{2}{l|}{ case $2 \quad \alpha=4^{\circ}$} \\
\hline & & (a) & (b) & (c) & $\begin{array}{c}(\mathrm{a})+(\mathrm{b}) \\
+(\mathrm{c})\end{array}$ & (d) \\
\hline$H_{p 1}$ & $(\mathrm{t})$ & -510.1 & -68.3 & 0.0 & -576.8 & -458.3 \\
$H_{p 2}$ & $(\mathrm{t})$ & -510.3 & 68.3 & 0.0 & -440.5 & -513.5 \\
$u$ & $(\mathrm{~m})$ & -0.227 & 0.0 & 0.0 & -0.227 & -0.329 \\
$\phi \times 10^{-3}(\mathrm{rad})$. & 0.0 & 2.055 & 0.0 & 2.055 & -1.553 \\
$v$ & $(\mathrm{~m})$ & 0.0 & 0.0 & 4.256 & 4.256 & 4.368 \\
$\bar{v}$ & $(\mathrm{~m})$ & 0.0 & 0.0 & 4.031 & 4.031 & 4.131 \\
$\theta$ & $(\mathrm{rad})$. & 0.0 & 0.0 & 0.140 & 0.140 & 0.147 \\
\hline
\end{tabular}

\begin{tabular}{ll|c|c|c|c||c}
\multicolumn{2}{c|}{ case $3 \quad \alpha=-4^{\circ}$} \\
\hline & & (a) & (b) & (c) & $\begin{array}{c}\text { (a) }+(\mathrm{b}) \\
+(\mathrm{c})\end{array}$ & $(\mathrm{d})$ \\
\hline$H_{p 1}$ & $(\mathrm{t})$ & 418.0 & 18.9 & 0.0 & 436.9 & 562.1 \\
$H_{p 2}$ & $(\mathrm{t})$ & 418.0 & -18.9 & 0.0 & 399.1 & 348.8 \\
$u$ & $(\mathrm{~m})$ & 0.186 & 0.0 & 0.0 & 0.186 & 0.117 \\
$\phi \times 10^{-3}$ (rad.) & 0.0 & -0.570 & 0.0 & -0.570 & -3.893 \\
$v$ & $(\mathrm{~m})$ & 0.0 & 0.0 & 3.967 & 3.967 & 3.889 \\
$\bar{v}$ & $(\mathrm{~m})$ & 0.0 & 0.0 & 3.761 & 3.761 & 3.683 \\
$\theta$ & (rad.) & 0.0 & 0.0 & 0.128 & 0.128 & 0.124 \\
\hline
\end{tabular}

力は吊構造の断面力を用いて求めることができる ${ }^{10)}$ が, 紙面の都合上省略する.

\section{1. 結語}

本論は補剛析の道路縦断曲線による初期曲率を含む連 成を考慮した 吊橋の 静的基礎方程式を 誘導するととも に, 3 分力を考慮した風荷重を受ける吊橋の変形および 応力について報告したものである. 得られた結果を要約 すると,

（1）誘導した基礎方程式は曲率が零の場合には力の つり合い式が得られた結果と実質的に同じものである.

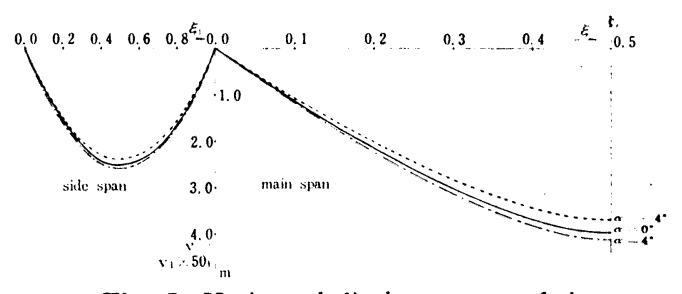

Fig. 7 Horizontal displacement $v$ of the stiffening truss

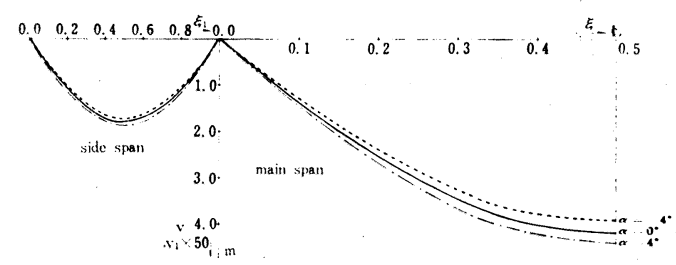

Fig. 8 Horizontal displacement $\bar{v}$ of the cable

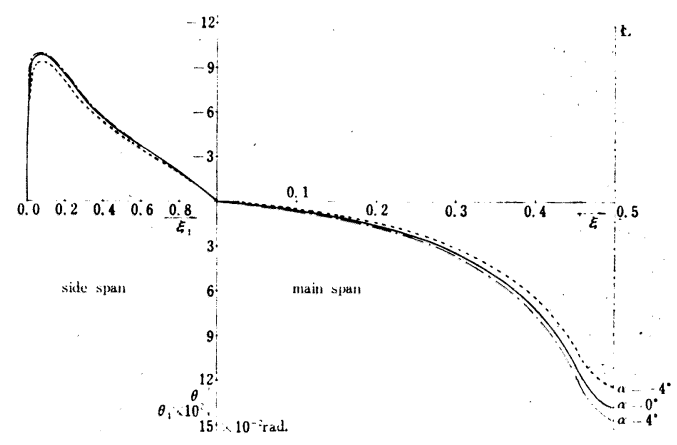

Fig. 9 Slope angle of rotation $\theta$ of the hanger

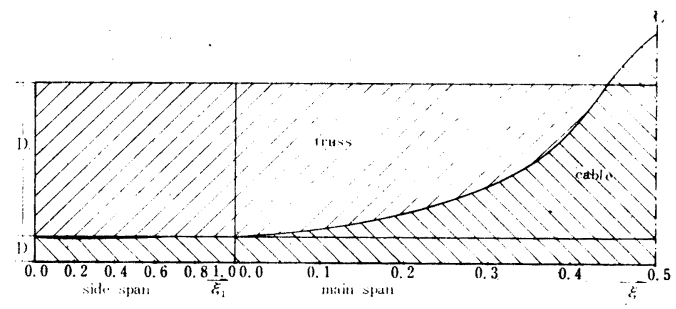

Fig. 10 Distribution of wind pressure on the cable and the stiffening truss 


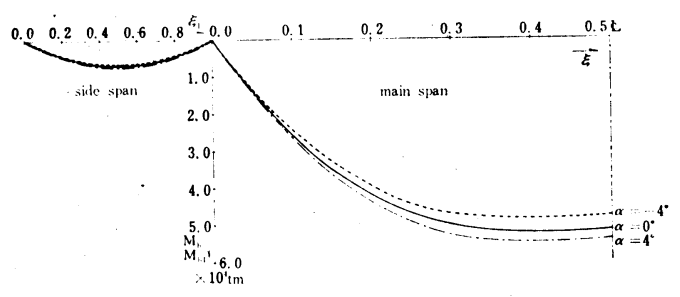

Fig. 11 Bending moment $M_{h}$ of the stiffening truss

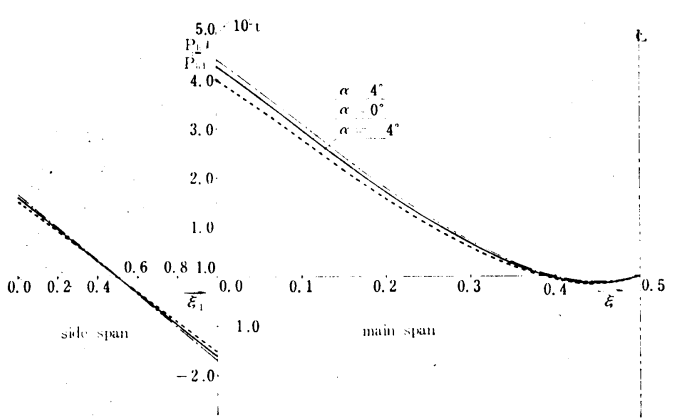

Fig. 12. Shearing force $Q_{h}$ of the stiffening truss

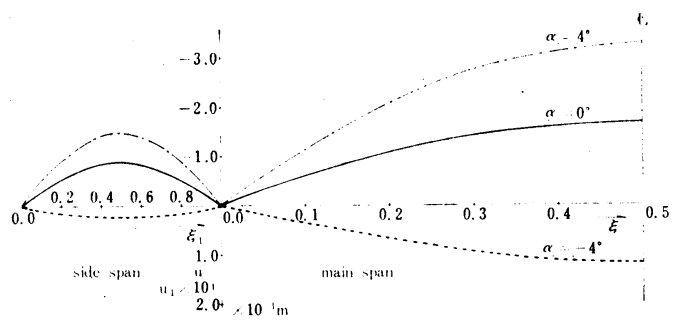

Fig. 13 Vertical displacement $u$ of the stiffening truss

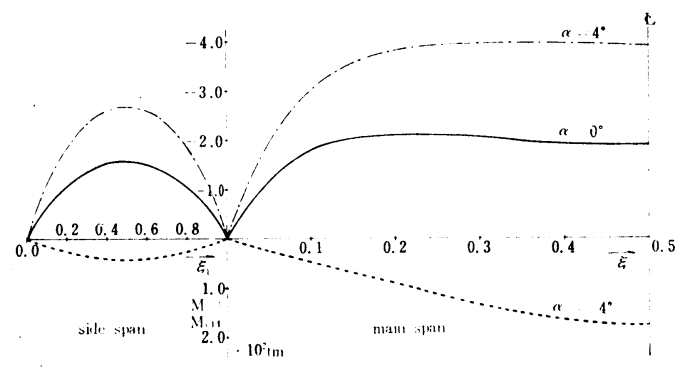

Fig. 14 Bending moment $M_{v}$ of the stiffening truss

また, 連成を無視すれば従来の非連成法の鉛直変位, 水 平横変位およびねじりの基礎方程式と一致する.

（2）ケーブルの鉛直および水平横変位を同時に考虑 したケーブル方程式を誘導した.

（3）基礎方程式の解法として変位の適合条件式とし て得られるハンガーの傾斜角を未知数に加える解法を採 用した.このことによってフーリエ級数の収束を従来の 解法より速くすることができた.

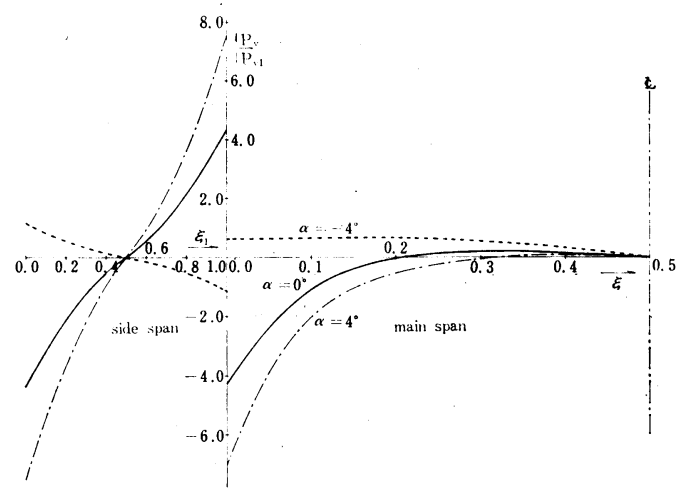

Fig. 15 Shearing force $Q_{v}$ of the stiffening truss

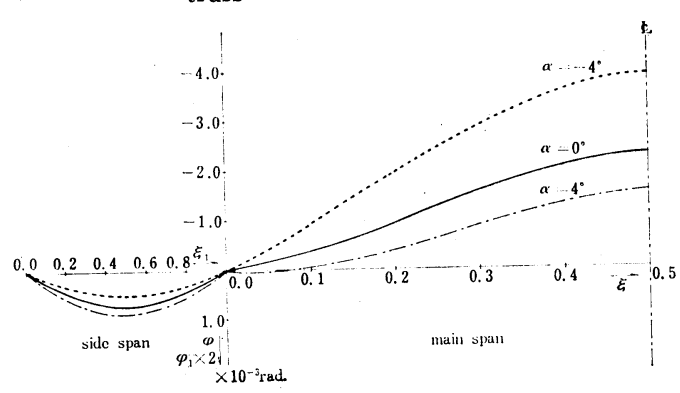

Fig. 16 Torsional angle $\phi$ of the stiffening truss

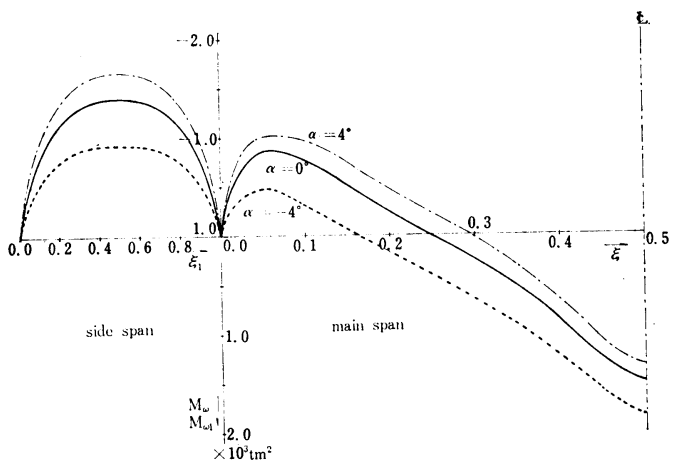

Fig. 17 Warping torsional moment $M_{\omega}$ of the stiffening truss

（4）補剛桁およびケーブルの水平横変位はケーブル の活荷重水平張力, 初期曲率および他の荷重の成分の影 響をほとんど受けず, 従来の抗力のみを用いた結果と合 致する.

（5）補剛桁の鉛直変位はケーブルの活荷重水平張力 の影響を著しく受ける. 鉛直変位のみを考慮したケーブ ルの活荷重水平張力を用いると鉛直変位を打ち消すよう にケーブルの水平張力が決定される. また, 鉛直方向の 曲げモーメントおよびせん断力もケーブルの活荷重水平 張力の影響を受けて減少する.

（6）ケーブルの鉛直変位のみならず水平横変位をも 含んだケーブル方程式を用いると, 水平横変位と連成す 


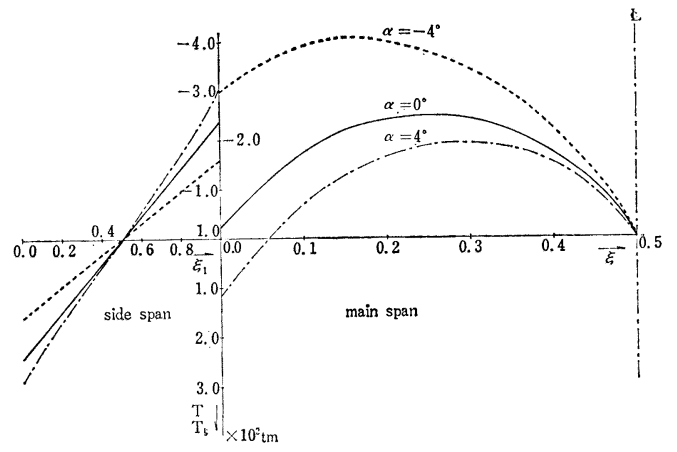

Fig. 18 Torsional moment $T$ of the stiffening truss

る補剛析およびケーブルの鉛直変位を生ずる．この変位 は揚力による鉛直変位と比べて無視できないものであ る.したがって, 3 分力を考慮した吊橋の連成解析には 水平横変位を考慮したケーブル方程式を採用しなければ ならない.

（1）補剛枌のねじりもケーブルの活荷重水平張力の 影響を受け，これを無視する場合よりも半分以下に減少 する・

（8）補剛析の初期曲率および補剛桁の重心上上弦材 中心の距離の存在によって抗力による水平横変位がねじ りを連成するが，その大きさは荷重による補剛桁自身の 変形と同程度であるために無視することができない.

（9）非連成法と連成法とを比較したところ，水平横 変位については非連成法で十分であるが，鉛直変位およ びねじりには両者の間にかなりの差が見らけられた．特 にねじりについては吊橋の構造特性を考慮した解析が必 要で, ねじり荷重のみを考慮した取扱いでは不十分であ る.

（10）補剛桁の鉛直変位およびねじりは風の迎え角の 影響を大きく受けるが，水平横変位については小さい.

（11）迎え角の影響を考慮した場合が，迎え角が零の 場合よりも大きな変位, したがって断面力を生ずること になる．鉛直方向の変位，断面力については迎え角が正 の場合, すなわち風が補剛桁を吹き上げる方向に作用す る場合が不利である. 逆に補剛桁のねじりおよび断面力 については迎え角が負の場合が不利となる。

以上の結果によって，長支間吊橋において風の抗力に よる水平横変位が卓越する場合にはケーブルの水平横変 位によって補剛桁の負の鉛直変位が連成し，また，補剛 桁の初期曲率や補剛桁の重心と上弦材中心の距離の存在 のために補剛桁の負のねじりが連成することが確認され た. したがって， 3 分力を考慮した吊橋の解析にはかか る構造特性を考慮した取扱いが必要であることが立証さ れた.
謝辞：本研究をまとめるにあたって，吊橋の基礎 方程式を力のつり合(式 ${ }^{16)}$ から誘導し, 貴重なデータを まとめられた日本道路公団 古道氏，本題の基礎方程式 の誘導に際して適確なご助言をいただいた本学 築地教 授，吊橋の解析についてご教示いただいた大阪大学 小 松教授, 西村講師, 東京大学 宮田助教授ならびに本四 公団 林氏に記して深く感謝するものである. また，本 稿をまとめるにあたっては, 九州大学 㯪木助教授のご 助言を得た・記して謝意を表する次第である・最後に本研 究の数值解析は九州大学大型計算機センターの FACOM 230-75 によったことを付記する.

\section{参 考 文 献}

1）高橋：連成を考虑した吊橋の基礎方程式について（第 1 報：微小変形の場合), 土木学会第 30 回年次学術講演会 概要集, 第 1 部, pp. 401 403, 昭和 50 年 11 月.

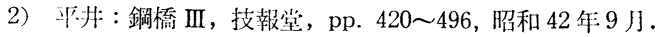

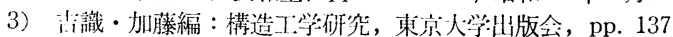
$\sim 162$, 昭和 43 年 12 月.

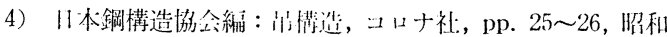
50 件 11 万.

5) Moisseiff, L.S., Lienhard, F : Suspension Bridges under the Ac- tion of Lateral Forces, Trans. of ASCE, Vol. 98, pp. 1080 1141, 1933.

6) Topaloff, B. : Stationarer Winddruck auf Hängebrücken, Der Stablbau, Vol. 5, pp. 109 113, 1954.

7) Erzen, C.Z. : Lateral Bending of Suspension Bridges, Pro. ASCE., Vol. 81, pp. 663-1 663-8, 1955.

8) Ito, M. : The Lateral Motion of Suspension Bridges, Trans. of JSCE, No. 81, pp. 10 16, 1962.

9）小西 編：鋼橋 設計編 II, 丸咅，pp. 1073 1078, 昭和 51 年 1 月.

10）小松・西村 : 横荷重を受ける吊橋の変形と応力について, 土木学会論文報告集, 第 248 号, pp. $55 \sim 67$, 昭和 51 年 4 月.

11) Shimada, S. : Programming for Digital Computation of Suspension Bridges under Vertical, Horizontal and Torsional Loadings, Trans. of JSCE, No. 102, pp. 1 6, Feb. 1964.

12）倉西・越後：吊橋の側方への変形について，土木学会第 29 回年次学術講演会講演概要集, 第 1 部, pp. 383 384, 昭和 49 年 10 月.

13）奥村：長支間橋梁に扔ける鋼構造の問題点，土木学会誌， Vol. 61, Annual '76, pp. 5〜7, 昭和 51 年 4 月.

14）築地：初期曲率，㸚じれ率を有する薄肉断面曲線ばりの 基礎方程式, 土木学会論文報告集, 第 230 号, pp. 11 22,1974 年 10 月.

15) Washizu, K. : Some Considerations on a Naturally Curved and Twisted Slender Beam, Jour. of Math. and Phys. Vol. 43, No. 2, pp. 111 116, 1964.

16) Timoshenko, S.P. and Young, D.H.: Theory of Structures, 2nd Edition, p. 530, 1965.

17）日本道路公団関門建設所関門架橋工事事務所：風荷重を 受ける吊橋の変形と応力, 昭和 45 年 5 月.

18）土木学会本州四国連絡橋鋼上部構造研究小委員会解析分 科会 : 本州四国連絡橋鋼上部構造に関する調查研究報告 書, 別冊 6 , 吊橋のねじり解析, 昭和 48 年 3 月.

(1977.8.25 • 受付) 